\title{
Review \\ Evolution of the Role of Radiotherapy for Anal Cancer
}

\author{
Edward Christopher Dee $\left.{ }^{1} \mathbb{(}\right)$, James D. Byrne ${ }^{2}$ and Jennifer Y. Wo ${ }^{1,3, *}$ \\ 1 Harvard Medical School, 25 Shattuck St., Boston, MA 02115, USA; Edward_Dee@hms.harvard.edu \\ 2 Harvard Radiation Oncology Program, Harvard Medical School, Boston, MA 02115, USA; \\ jdbyrne@partners.org \\ 3 Department of Radiation Oncology, Massachusetts General Hospital, 100 Blossom St., Boston, MA 02114, USA \\ * Correspondence: jwo@mgh.harvard.edu; Tel.: +1-617-726-2000
}

Citation: Dee, E.C.; Byrne, J.D.; Wo, J.Y. Evolution of the Role of Radiotherapy for Anal Cancer. Cancers 2021, 13, 1208. https:// doi.org/10.3390/cancers13061208

Academic Editors: Christopher L. Hallemeier and Krishan R. Jethwa

Received: 29 December 2020

Accepted: 6 March 2021

Published: 10 March 2021

Publisher's Note: MDPI stays neutral with regard to jurisdictional claims in published maps and institutional affiliations.

Copyright: (c) 2021 by the authors. Licensee MDPI, Basel, Switzerland. This article is an open access article distributed under the terms and conditions of the Creative Commons Attribution (CC BY) license (https:// creativecommons.org/licenses/by/ $4.0 /)$.
Simple Summary: Prior to the 1980s, primary management of localized anal cancer was surgery. Dr. Norman Nigro and colleagues found that neoadjuvant chemoradiotherapy with 5-fluorouracil and mitomycin $\mathrm{C}$ afforded complete response, obviating the need for surgery upfront. Advancements in radiotherapy delivery using intensity-modulated radiation therapy (IMRT) and image-guided radiation have resulted in reductions in radiation-associated adverse effects, allowing for the delivery of greater doses of radiation. Ongoing prospective trials are attempting to improve IMRT-based treatment of locally advanced disease with efforts to increase personalized treatment. Trials of newer modalities such as proton therapy are underway. In this review, we present the evolution of radiotherapy for anal cancer and describe recent advances to contextualize ongoing studies and inform future directions in efforts to mitigate treatment toxicities, further personalize treatment, and improve oncologic outcomes.

\begin{abstract}
Prior to the 1980s, the primary management of localized anal cancer was surgical resection. Dr. Norman Nigro and colleagues introduced neoadjuvant chemoradiotherapy prior to abdominoperineal resection. Chemoradiotherapy 5 -fluorouracil and mitomycin $\mathrm{C}$ afforded patients complete pathologic response and obviated the need for upfront surgery. More recent studies have attempted to alter or exclude chemotherapy used in the Nigro regimen to mitigate toxicity, often with worse outcomes. Reductions in acute adverse effects have been associated with marked advancements in radiotherapy delivery using intensity-modulated radiation therapy (IMRT) and image-guidance radiation delivery, resulting in increased tolerance to greater radiation doses. Ongoing trials are attempting to improve IMRT-based treatment of locally advanced disease with efforts to increase personalized treatment. Studies are also examining the role of newer treatment modalities such as proton therapy in treating anal cancer. Here we review the evolution of radiotherapy for anal cancer and describe recent advances. We also elaborate on radiotherapy's role in locally persistent or recurrent anal cancer.
\end{abstract}

Keywords: chemoradiotherapy; 5-fluorouracil; mitomycin C; intensity-modulated radiation therapy; RTOG 0529; Nigro regimen

\section{Introduction: Surgery Prior to the Introduction of Chemoradiotherapy}

An estimated 8590 new cases and 1350 deaths in the United States were attributable to anal cancer in 2020 [1], with increasing incidence in some populations [2]. Human papilloma virus and immunosuppression are two key risk factors for anal cancer [3-6]. Historically defined prognostic factors for patients with anal cancer include gender, stage, tumor size and nodal status [7]. The presence of human papilloma virus DNA may also be associated with improved outcomes [8]. Recent studies have also suggested low pretreatment hemoglobin as a poor prognostic factor [9]. Recent studies also suggest immune status-such as the ratio of neutrophils to lymphocytes, the ratio of platelets to lymphocytes, and C-reactive protein-as potential prognostic factors in patients with anal cancer [10]. 
The primary goal of the treatment of localized anal cancer is locoregional control with the preservation of organ function. Prior to the 1980s, the primary management of localized anal cancer was surgical resection, involving abdominoperineal resection (APR) requiring permanent colostomy [11]. Large surgical series demonstrated 5-year overall survival after APR ranging from 40-70\% [12-16]. Abdominoperineal resection also yielded significant morbidity due to lack of sphincter preservation and high rates of sexual and urinary dysfunction $[14,17,18]$.

In an effort to improve operability, Norman Nigro and colleagues at Wayne State University attempted neoadjuvant chemoradiotherapy; their early experience demonstrated a complete response in the first three patients treated with chemoradiotherapy, published in 1974 [19]. Subsequent studies supported local excision instead of APR, and eventually, nonsurgical primary management [19-21].

The Nigro regimen used 30 Gray (Gy) of external beam radiation therapy with mitomycin C (MMC; $10-15 \mathrm{mg} / \mathrm{m}^{2}$ on day 1 ) and 2 cycles of 5 -fluorouracil (5FU; $1000 \mathrm{mg} / \mathrm{m}^{2}$ on days 1-4 and days 29-32), achieving a complete response in the first three treated patients [19]. In a follow-up study with 45 patients, $38(84 \%)$ patients were rendered free of disease with nonsurgical management; Leichman et al. wrote: "It appears that the adjuvant chemotherapy does not merely 'sensitize' the local tumor for the radiation therapy but, in combination with radiation, 'kills' local tumor" [22]. The study also demonstrated a 5 -year overall survival of $67 \%$ and colostomy-free survival of 59\% [22].

Seminal work from Jean Papillon published in the 1980s also supported the establishment of nonsurgical treatment of anal cancer [23-25]. A series of 121 patients with anal cancer treated with radiation, with or without subsequent surgery, the rate of cancer-specific mortality was $18 \%$ [24]. Of patients for whom treatment was curative, three-quarters maintained normal anal function [24]. Another series of 221 patients treated with external beam radiation to $30 \mathrm{~Gy}$ and iridium implant boost to 10-20 Gy resulted in a 5-year overall survival rate of $65 \%, 90 \%$ of whom maintained normal anal function [23]. In a subsequent series, 222 patients were treated with external beam irradiation followed by iridium implant, $80 \%$ of patients experienced tumor control and $90 \%$ retained normal anal function [25]. The authors also suggested "chemotherapy during the first days of irradiation ... to reinforce the efficacy of treatment and increase the chance of anal preservation" [25].

Although APR remained an option for patients with persistent or recurrent disease, with a 5-year survival rate up to $92 \%$ [20,22,26-39], subsequent studies assessing primary treatment options for localized anal cancer sought to optimize upfront nonsurgical management.

\section{Chemoradiotherapy versus Radiotherapy Alone: ACT I and EORTC}

In light of adverse effects associated with concurrent 5FU and MMC with radiation therapy, other studies in the 1980s provided evidence that radiotherapy alone produced promising outcomes [40,41]. A key retrospective series demonstrated 3-year overall survival of $75 \%$ for patients receiving radiotherapy alone $[40,41]$. Another series demonstrated 5 -year overall survival rates upwards of $60-70 \%$ with radiation alone, with maintenance of sphincter function in the vast majority of patients [23]. The success of regimens consisting of radiotherapy alone called into question the role of chemoradiotherapy in the 1980s [42]. However, non-retrospective evidence comparing chemoradiotherapy vs. radiation alone suggested improved local control rates for chemoradiotherapy [43]. Therefore, two randomized controlled trials were proposed to compare head-to-head chemoradiotherapy vs. radiotherapy alone.

In the 1996 United Kingdom Coordinating Committee on Cancer Research (UKCCCR) Anal Cancer Trial (ACT I) trial, 585 patients were randomized to radiotherapy alone (45 Gy with external beam radiotherapy (EBRT) and either 15 Gy EBRT boost or 25 Gy brachytherapy boost) or chemoradiotherapy (similarly 45 Gy with EBRT and either 15 Gy EBRT boost or $25 \mathrm{~Gy}$ brachytherapy boost, with concurrent MMC at $12 \mathrm{mg} / \mathrm{m}$ [2]. on day 1 and $5 F U$ at $1000 \mathrm{mg} / \mathrm{m}^{2}$ for 4 days or $750 \mathrm{mg} / \mathrm{m}^{2}$ for 5 days during the first and last week of radiation) [44]. The study found no significant difference in 3-year overall survival 
between chemoradiotherapy and radiotherapy ( 65 vs. $58 \%, p=0.25$ ); however, 5-year local control for chemoradiotherapy was significantly greater than for radiotherapy alone (68 vs. $43 \%, p<0.001)[44,45]$.

The 1997 European Organization for Research and Treatment of Cancer (EORTC) trial randomized 110 patients to radiation therapy (45 Gy EBRT with 15 Gy or 30 Gy EBRT boost) or chemoradiotherapy (45 Gy EBRT with 15 Gy or 30 Gy EBRT boost with concurrent 5FU at $750 \mathrm{mg} / \mathrm{m}^{2}$ continuous infusion on days $1-5$ and $29-33$ and MMC at $15 \mathrm{mg} / \mathrm{m}^{2}$ one day 1) [46]. The study found no significant difference in 3-year overall survival between groups (65 vs. $72 \%, p=0.17$ ); however, the colostomy-free survival was $72 \%$ for patients who received chemoradiotherapy vs. $40 \%$ for patients treated with radiotherapy alone [46]. Notably, chemoradiotherapy was associated with improved 5-year local control compared with radiotherapy alone (68 vs. $51 \%, p=0.02$ ) [46].

The UKCCCR/ACT1 and EORTC trials were similar in their use of 45 Gy radiotherapy and comparable doses of concurrent 5FU and MMC, their 6-week post-treatment break and radiotherapy boost to patients with partial and complete response, and definitive surgery after the 6 -week break for nonresponsive disease $[44,46]$. Both trials were also similar in their demonstration of improved local control and colostomy-free survival in the chemoradiotherapy arm $[44,46]$. Long-term 13-year follow-up of the UKCCCR/ACT1 trial also demonstrated significantly lower risk of cancer-specific mortality in the group that received combined therapy [45]. However, for both trials acute toxicities were greater in the chemoradiotherapy arm, late toxicities were similar between treatment groups [44-47].

Taken together, the UKCCCR/ACT1 and EORTC trials in the late 1990s support the role of chemoradiotherapy compared to radiotherapy alone in providing superior control of local disease, colostomy-free survival, and disease-specific survival $[44,46]$. The lack of difference in overall survival has been attributed to the role of salvage APR-despite surgical morbidity-in controlling and eliminating persistent or recurrent disease. These studies established chemoradiotherapy as standard-of-care for anal cancer. Key completed trials are summarized in Table 1.

Table 1. Key Completed Trials.

\begin{tabular}{|c|c|c|c|c|}
\hline Trial & Inclusion & Design & Treatments & Results \\
\hline \multicolumn{5}{|c|}{ Radiotherapy vs. chemoradiotherapy } \\
\hline $\begin{array}{l}\text { UKCCCR Anal Cancer } \\
\text { Trial (ACT I) }[44,45]\end{array}$ & $\begin{array}{l}\text { Localized and } \\
\text { metastatic, barring } \\
\text { exclusion criteria (e.g., } \\
\text { previous treatment, } \\
\text { cancer at another site, } \\
\text { or tumor considered } \\
\text { suitable for local } \\
\text { excision only [T1 N0]) }\end{array}$ & $\begin{array}{l}585 \text { patients; } 295 \text { in the } \\
\text { CRT arm and } 290 \text { in the } \\
\text { RT-only arm }\end{array}$ & $\begin{array}{l}45 \text { Gy EBRT and } 15 \text { Gy } \\
\text { EBRT boost or } 25 \text { Gy } \\
\text { brachytherapy boost, } \\
\text { with vs. without } \\
\text { concurrent MMC } \\
\text { and 5FU }\end{array}$ & $\begin{array}{l}\text { 42-month follow-up: CRT vs. RT alone } \\
\text { locoregional recurrence relative risk } \\
0.54(95 \% \text { CI } 0.42-0.69, p<0.0001) \\
\text { Anal cancer-specific mortality relative } \\
\text { risk } 0.71(95 \% \text { CI } 0.53-0.95, p=0.02) \\
\text { 12-year follow-up: for every } 100 \\
\text { patients treated with CRT, } 25.3 \text { fewer } \\
\text { patients experienced locoregional } \\
\text { recurrence and } 12.5 \text { fewer experienced } \\
\text { anal cancer-specific death compared to } \\
\text { the RT-only cohort }\end{array}$ \\
\hline EORTC [46] & $\begin{array}{l}\text { T3-4N0-3 or T1-2N1-3 } \\
\text { anal cancer }\end{array}$ & $\begin{array}{l}110 \text { randomized, } 103 \\
\text { eligible, } 51 \text { to CRT and } \\
52 \text { to } \mathrm{RT} \text { alone }\end{array}$ & $\begin{array}{l}45 \text { Gy EBRT with } 15 \text { Gy } \\
\text { or } 30 \text { Gy EBRT boost } \\
\text { with vs. without } \\
\text { concurrent } 5 \text { FU } \\
\text { and MMC }\end{array}$ & $\begin{array}{l}\text { 5-year local control greater for CRT vs. } \\
\text { RT alone ( } 68 \text { vs. } 51 \%, p=0.02 \text { ) } \\
\text { 3-year overall survival similar between } \\
\text { groups ( } 65 \text { vs. } 72 \%, p=0.17 \text { ) }\end{array}$ \\
\hline \multicolumn{5}{|l|}{ Omission of MMC } \\
\hline $\begin{array}{l}\text { RTOG 87-04/ECOG } \\
1289 \text { [48] }\end{array}$ & $\begin{array}{l}\text { Patients with any } \\
\text { epidermoid } \\
\text { malignancy of the anal } \\
\text { canal in which the } \\
\text { primary tumor was } \\
\text { measurable (any T or } \\
\text { N stage) }\end{array}$ & $\begin{array}{l}310 \text { randomized, } 295 \\
\text { eligible, } 145 \text { to EBRT + } \\
\text { 5FU, } 146 \text { EBRT + 5FU } \\
+\mathrm{MMC}\end{array}$ & $\begin{array}{l}\text { 45-50.4 Gy EBRT with } \\
\text { 5FU with vs. } \\
\text { without MMC }\end{array}$ & $\begin{array}{l}\text { MMC associated with greater } \\
\text { colostomy-free survival ( } 71 \% \text { for } 5 \mathrm{FU} \\
\text { and MMC vs. } 59 \% \text { for } 5 \mathrm{FU} \text { alone; } \\
p=0.014 \text { ) and improved disease-free } \\
\text { survival ( } 73 \% \text { for } 5 \mathrm{FU} \text { and MMC vs. } \\
51 \% \text { for } 5 \mathrm{FU} \text { alone; } p=0.0003 \text { ) } \\
\text { No OS difference and greater toxicity } \\
\text { with MMC }\end{array}$ \\
\hline
\end{tabular}


Table 1. Cont.

\begin{tabular}{|c|c|c|c|c|}
\hline Trial & Inclusion & Design & Treatments & Results \\
\hline \multicolumn{5}{|l|}{ Cisplatin vs. MMC } \\
\hline RTOG 98-11 [7,49] & $\begin{array}{l}\text { T2-4NanyM0 (T1 or } \\
\text { M1 excluded) }\end{array}$ & $\begin{array}{l}682 \text { randomized, } 649 \\
\text { eligible, } 325 \text { to } \mathrm{RT}+ \\
5 \mathrm{FU} / \mathrm{MMC} \text { and } 324 \\
\text { to } \mathrm{RT}+ \\
5 \mathrm{FU} / \text { cisplatin }\end{array}$ & $\begin{array}{l}45 \text { Gy with } \\
\text { allowance for } 10-14 \\
\text { Gy boost with } 5 \mathrm{FU}+ \\
\text { MMC vs. RT }+5 \mathrm{FU}+ \\
\text { cisplatin }\end{array}$ & $\begin{array}{l}\text { 5-year colostomy-free survival } \\
\text { improved in MMC arm (72 vs. } \\
65 \%, p=0.05) ; \text { DFS improved in } \\
\text { MMC arm (67.8 vs. } 57.8 \% \text {, } \\
p=0.006) \text {; OS improved in MMC } \\
\text { arm ( } 78.3 \text { vs. } 70.7 \%, p=0.026)\end{array}$ \\
\hline ACT II [50] & $\begin{array}{l}\text { Any T, any N, no } \\
\text { distant metastases }\end{array}$ & $\begin{array}{l}940 \text { randomized, } 472 \\
\text { in } \mathrm{RT}+5 \mathrm{FU} / \mathrm{MMC} \\
\text { cohort and } 468 \text { in } \mathrm{RT} \\
+5 \mathrm{FU} / \text { cisplatin } \\
\text { cohort }\end{array}$ & $\begin{array}{l}50.4 \text { Gy with } \\
\text { continuous 5FU, } \\
\text { with bolus cisplatin } \\
\text { or MMC }\end{array}$ & $\begin{array}{l}\text { 3-year colostomy-free similar }(68 \% \\
\text { in MMC arm, } 67 \% \text { in cisplatin arm, } \\
p=0.94) \text {; DFS similar }(69 \% \text { in both } \\
\text { arms, } p=0.63) \text {; OS similar }(79 \% \text { in } \\
\text { MMC arm, } 77 \% \text { in cisplatin arm, } \\
p=0.7)\end{array}$ \\
\hline
\end{tabular}

RT dose escalation vs. de-escalation

\begin{tabular}{|c|c|c|c|c|}
\hline $\begin{array}{l}\text { RTOG 92-08 } \\
{[36,48,51]}\end{array}$ & Any except T1N0 & $\begin{array}{l}\text { Single-arm phase II } \\
\text { study with } 47 \\
\text { patients: standard } \\
\text { chemotherapy } \\
\text { (5FU/MMC) + high } \\
\text { dose RT }\end{array}$ & $\begin{array}{l}2 \text { weeks of } \mathrm{RT} \text {, then } \\
\text { mandatory gap, total } \\
\text { RT dose } 59.4 \mathrm{~Gy}\end{array}$ & $\begin{array}{l}\text { Median follow-up duration } \\
12 \text { years, estimated 5-year DFS } \\
53 \% \text {; estimated 5-year } \\
\text { colostomy-free survival 58\%; } \\
\text { estimated 5-year OS } 85 \%\end{array}$ \\
\hline ACCORD-03 [52] & $\begin{array}{l}\text { Patients with tumors } \\
\geq 40 \mathrm{~mm} \text {, or } \\
<40 \mathrm{~mm} \text { and } \mathrm{N} 1-3 \mathrm{M} 0\end{array}$ & $\begin{array}{l}2 \times 2 \text { factorial } \\
\text { randomization: } \\
\text { neoadjuvant } \\
\text { chemotherapy and } \\
\text { CRT (5FU/cisplatin) } \\
+/- \text { high-dose RT; } \\
283 \text { of } 307 \text { achieved } \\
\text { full treatment }\end{array}$ & $\begin{array}{l}45 \text { Gy } / 25 \text { fractions } \\
\text { with standard dose } \\
\text { boost ( } 15 \text { Gy) vs. } \\
\text { high-dose boost } \\
\text { ( } 20-25 \text { Gy) with } \\
\text { EBRT or } \\
\text { brachytherapy }\end{array}$ & $\begin{array}{l}\text { Similar colostomy-free survival } \\
\text { (the primary endpoint) for } \\
\text { standard vs. escalated boost dose } \\
\text { ( } 78 \text { vs. } 74 \%, p=0.067) \text {; } \\
\text { nonsignificant improvement in } \\
5 \text {-year local control rate for } \\
\text { escalated boost dose }(83.1 \% \text { ) vs. } \\
\text { standard-boost }(78.2 \%)\end{array}$ \\
\hline \multicolumn{5}{|c|}{ Intensity-modulated radiotherapy (IMRT) } \\
\hline RTOG 05-29 [53] & T2N0, T3-4N0-3 & $\begin{array}{l}\text { Phase II trial } \\
\text { evaluating CRT with } \\
\text { concurrent } \\
\text { 5FU / MMC and } \\
\text { dose-painted IMRT }\end{array}$ & $\begin{array}{l}\text { T2N0: } 42 \text { Gy elective } \\
\text { nodal and } 50.4 \text { Gy } \\
\text { anal tumor PTVs in } \\
28 \text { fractions } \\
\text { T3-4N0-3: } 45 \text { Gy } \\
\text { elective nodal and } \\
50.4 \text { Gy }<3 \mathrm{~cm} \text { or } \\
54 \text { Gy }>3 \mathrm{~cm} \\
\text { metastatic nodal and } \\
54 \text { Gy anal tumor } \\
\text { PTVs in } 30 \text { fractions }\end{array}$ & $\begin{array}{l}\text { Dose-painted IMRT associated } \\
\text { with reduced grade } 3+ \\
\text { genitourinary and gastrointestinal } \\
\text { toxicity ( } 22 \text { vs. } 36 \%, p=0.014) \text {, and } \\
\text { grade } 3+\text { dermatologic toxicity ( } 20 \\
\text { vs. } 47 \%, p<0.001 \text { ) when compared } \\
\text { to the historical RTOG } 98-11 \\
\text { MMC arm }\end{array}$ \\
\hline
\end{tabular}

Pencil beam scanning proton beam radiotherapy (PBS-PT)

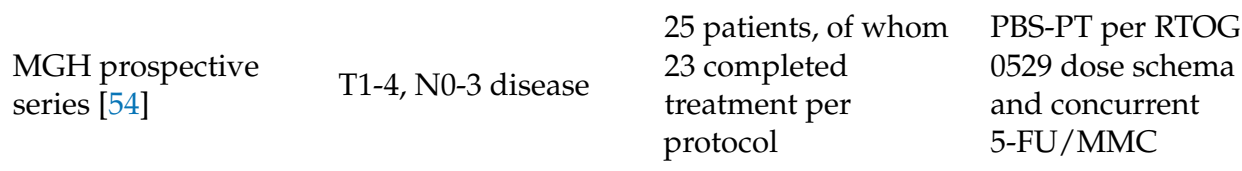

Grade 3+ radiation dermatitis rate $24 \%$; overall rate of clinical complete response was $88 \%$; 2-year local failure rate $12 \%$, colostomy-free survival $72 \%$, progression-free survival $80 \%$, and overall survival $84 \%$ 
Table 1. Cont.

\begin{tabular}{|c|c|c|c|c|}
\hline Trial & Inclusion & Design & Treatments & Results \\
\hline \multicolumn{5}{|l|}{ Immunooncology } \\
\hline $\begin{array}{l}\text { Multicenter US } \\
\text { prospective series } \\
\text { [55] }\end{array}$ & $\begin{array}{l}\text { Patients with anal } \\
\text { cancer (squamous } \\
\text { cell only, } \\
\text { adenocarcinoma } \\
\text { excluded) and at } \\
\text { least one previous } \\
\text { systemic therapy for } \\
\text { surgically } \\
\text { unresectable or } \\
\text { metastatic disease }\end{array}$ & $\begin{array}{l}\text { Phase II study of } \\
37 \text { patients with } \\
\text { metastatic disease }\end{array}$ & $\begin{array}{l}\text { Nivolumab IV every } \\
2 \text { weeks }(3 \mathrm{mg} / \mathrm{kg})\end{array}$ & $\begin{array}{l}\text { Of } 37 \text { patients who received at } \\
\text { least one dose of nivolumab, } \\
9(24 \%) \text { demonstrated tumor } \\
\text { response, of whom } 2 \text { experienced } \\
\text { a complete response }\end{array}$ \\
\hline
\end{tabular}

\section{Omission of Mitomycin C: RTOG 87-04/ECOG 1289}

The Radiation Therapy Oncology Group (RTOG) and Eastern Cooperative Oncology Group (ECOG) RTOG 87-04/ECOG 1289 trial evaluated the omission of mitomycin C (MMC) in concurrent chemoradiotherapy for patients with anal cancer. The inclusion of MMC in the Nigro protocol likely contributes to the majority of the adverse effects experienced by patients on the Nigro protocol and is associated with leukopenia, thrombocytopenia, nephrotoxicity, and pulmonary toxicity [47]. RTOG 87-04/ECOG 1289 randomized 310 patients to radiation (45-50.5 Gy) with $5 F U$ alone (1000 $\mathrm{mg} / \mathrm{m}^{2}$ on days $1-4$ and 29-32) vs. 5FU with MMC (10 mg/m² for two doses) [48]. The RTOG 87-04/ECOG 1289 trial demonstrated an association between the addition of MMC and higher colostomy-free survival $(71 \%$ for $5 \mathrm{FU}+\mathrm{MMC}$ vs. $59 \%$ for 5FU alone; $p=0.014)$; the trial also demonstrated an association between MMC and improved disease-free survival (73\% for 5FU and MMC vs. $51 \%$ for $5 \mathrm{FU}$ alone; $p=0.0003$ ). Although the addition of MMC did not improve overall survival and anal cancer-specific survival and was associated with greater toxicity (23 vs. $7 \%$ experiencing grade 4 or 5 toxicity, $p<0.001$ ) [48], the results of RTOG 87-04/ECOG 1289 support continued inclusion of MMC in the treatment of anal cancer.

\section{Cisplatin as a Possible Alternative to Mitomycin C: RTOG 98-11 and ACT II}

Due to cisplatin's efficacy in certain squamous cell cancers [56] and early studies demonstrating promising results in anal cancer $[39,57,58]$, RTOG 98-11 prospectively assessed cisplatin as a substitution for MMC. RTOG 98-11 randomizes 682 patients to either radiation with $5 \mathrm{FU}\left(1000 \mathrm{mg} / \mathrm{m}^{2}\right.$ on days $1-4$ and $\left.29-32\right)$ and MMC $\left(10 \mathrm{mg} / \mathrm{m}^{2}\right.$ on days 1 and 29), or induction chemotherapy with $5 F U$ (1000 $\mathrm{mg} / \mathrm{m}^{2}$ on days 1-4 and 29-32) and cisplatin (75 mg/m $\mathrm{m}^{2}$ on days 1 and 29) followed by chemoradiotherapy with 5FU and cisplatin (starting day 57). The primary tumor and perirectal nodes were treated to a minimum of $45 \mathrm{~Gy}$ in 25 fractions once a day, with advanced disease receiving an additional boost to 10-14 Gy. The initial publication found lower rates of colostomy in patients receiving MMC vs. cisplatin (10 vs. 19\%, $p=0.02$ ), although MMC was associated with greater toxicity; there was no difference in disease-free survival and overall survival at 5 years [49]. A subsequent publication of RTOG 98-11 demonstrated improved 5-year disease-free survival (67.8 vs. 57.8\%, $p=0.006)$ and 5-year overall survival (78.3 vs. 70.7\%; $p=0.026)$ in the MMC arm [7,59] The MMC arm also demonstrated nominally lower rates of local recurrence (20 vs. $26.4 \%, p=0.087)$ and colostomy (11.9 vs. $17.3 \%, p=0.074)[7,59]$ Of note, pooled analysis of RTOG 87-04/ECOG 1289 and RTOG 98-11 demonstrated an association between longer treatment time and increased colostomy failure, greater local failure rates, and worse disease-free survival [60], possibly introducing bias due to longer treatment time in the RTOG 98-11 cisplatin arm.

The ACT II trial assessed whether substituting cisplatin for MMC and whether the inclusion of maintenance chemotherapy improved outcomes in anal cancer [50]. Patients were 
randomized in a $2 \times 2$ fashion to F5U with MMC vs. 5FU with cisplatin, and observation vs. maintenance chemotherapy with 2 cycles of 5FU/cisplatin. At 6 months, rates of clinical complete response and grade 3-4 toxicity were similar between the MMC and cisplatin arms. Three-year rates of progression-free survival were similar in the maintenance vs. observation arms (74 vs. $73 \%, p=0.70)$ [50].

ACT II demonstrated that cisplatin and maintenance chemotherapy were not superior to standard-of-care. Furthermore, cisplatin administration requires intravenous hydration and greater anti-emetic therapy. Therefore, 5FU with MMC remain standard of care.

Of note, although trials in Europe have tended to use one cycle of MMC and trials in the US have tended to use two cycles, retrospective data comparing 5FU with one or two cycles of MMC found no difference in progression-free survival, cancers-specific survival, overall survival, and colostomy-free survival between both arms, with lower toxicity in patients receiving one cycle of MMC [61].

\section{Capecitabine as an Alternative to $5 \mathrm{FU}$}

Capecitabine has been investigated as an alternative to 5FU for anal cancer [62]. Capecitabine's relative ease of administration and potential radiosensitizer properties prompted further study of its role in anal cancer [62]. A phase II trial evaluated capecitabine $825 \mathrm{mg} / \mathrm{m}^{2}$ twice daily and MMC $15 \mathrm{mg} / \mathrm{m}^{2}$ on day 1 during radiation therapy and demonstrate a complete response rate at 6 months of $86 \% ; 7 \%$ of patients experienced partial response, and 7\% experienced disease progression [63]. In another phase II trial of capecitabine and MMC with radiotherapy, 77\% of patients experienced complete response, $16 \%$ experienced partial response, and 7\% experienced disease progression; $14 \%$ experienced locoregional relapse [64].

The role of capecitabine as an alternative to 5FU has also been supported by the experience in rectal cancer from the National Surgical Adjuvant Breast and Bowel Project R-04 (NSABP R-04) [65]. NSABP R-04 was a $2 \times 2$ trial that randomized 1608 patients with stage II or III rectal cancer to radiotherapy with continuous venous infusion 5FU or oral capecitabine, with or without oxaliplatin [65]. Patients treated with capecitabine compared to those treated with 5FU did not experience a significant difference in surgical downstaging, sphincter-sparing surgery, and pathologic complete response, lending support to the role of capecitabine in anal cancer [66].

A retrospective study of UK patients comparing toxicity experienced by patients treated with capecitabine/MMC vs. 5FU/MMC found similar rates of grade $\geq 3$ toxicity between groups (capecitabine/MMC 45 vs. 5FU/MMC 55\%, $p=0.35$ ) [67]. Furthermore, the rate of grade 3 hematologic toxicity was lower for patients who received capecitabine/MMC vs. 5FU/MMC (4 vs. 27\%, $p=0.001$ ) [67]. However, the lack of randomized phase III data specific to anal cancer has limited the universal adoption of capecitabine. Also, concerns remain regarding treatment adherence as treatment typically involves multiple tablets taken twice daily.

\section{Radiation Dose De-Escalation}

Given the risk of acute and late adverse effects from large radiation doses, de-escalation is also under investigation. The series presented in 1985 by Leichman et al. showed that for patients with T1-T2 tumors with close or involved margins treated with chemoradiotherapy, doses as low as $30 \mathrm{~Gy}$ could achieve local control rates of 90\% [22]. However, more recent retrospective studies suggest that doses $<50 \mathrm{~Gy}$ are associated with greater rates of local failure compared to doses $\geq 54 \mathrm{~Gy}$, although variation in tumor and patient characteristics as well as different types of chemotherapy and radiation field employed complicates the interpretation of these studies [57,68-71]. Given the variation in local control rates by tumor size and potential decrease in adverse effects with de-escalation [72-74], the ongoing ECOG-DECREASE study aims to assess the role of dose de-escalated chemoradiation for early stage anal cancer [75]. Patients will be randomized to standard-dose chemoradiation (28 fractions with MMC and either capecitabine or 5FU) or de-intensified chemoradiation 
(20-23 fractions with MMC and either capecitabine or 5FU). Primary endpoints include disease control (maintenance of 2-year disease control of $85 \%$ or higher in the dose de-escalated cohort) and health-related quality of life. [75]. The ongoing ACT III and ACT IV trials, discussed further below, will assess dose de-escalation in patients with T1-T2 disease [76].

\section{Radiation Dose Escalation}

The role of dose escalation has also been investigated. In the earlier RTOG 92-08 trial, a total dose of 59.4 Gy was delivered in 1.8 Gy fractions with a 2-week treatment break $[36,48,51]$. Patients treated with this higher dose had greater colostomy rates of $30 \%$, compared to $9 \%$ in RTOG 87-04, where patients received 45 Gy without a treatment break and similar chemotherapy as in RTOG 92-08 [36,48,51]. Late effects of dose escalation were not reported in the initial publication and subsequent updates [36,48,51].

However, data supporting variations in outcome by tumor size galvanized further investigation of dose escalation [72,73]. An analysis of RTOG 98-11 demonstrated that tumors with diameter $>5 \mathrm{~cm}$ were associated with lower 5-year disease-free survival and overall survival [72]. Another re-analysis of RTOG 98-11 found that 3-year colostomy failure rates differed by tumor size, with failure rates of $28 \%$ for patients with T4N1-3 disease vs. $4 \%$ for patients with T2N1-3 disease [73]. Therefore, investigators explored the use of adapted radiation dose escalation.

The ACCORD-03 trial was designed to assess high-dose RT boost based on initial treatment response [52]. In ACCORD-03, patients who responded to initial chemoradiotherapy received standard 15 Gy boost or dose-escalated 20-25 Gy boost (patients with complete response or $>80 \%$ tumor reduction received $20 \mathrm{~Gy}$; the rest received $25 \mathrm{~Gy}$ ). The doseescalated boost arm was treated with EBRT or LDR brachytherapy [52]. The trial found no difference in the primary endpoint of colostomy-free survival (78 vs. $74 \%, p=0.067$ ). However, ACCORD-03 demonstrated improved 5-year local control for the group treated with dose-escalated boost $(83.1 \%)$ vs. standard 15 Gy boost $(78.2 \%)$, although this difference was not significant [52]. Of note, since patients had a 3-week break prior to the boost in addition to induction chemotherapy, the possible association between increased overall treatment time and accelerated tumor repopulation [68] may have contributed to the study's findings.

A concern for dose escalation includes an increase in the risk of fecal incontinence [74]. A European study found that in a cohort treated with $56 \mathrm{~Gy}$, one-third of patients experienced fecal incontinence $[74,77,78]$. Very high doses delivered to the lamina propria and anal sphincter may also result in stricture and stenosis. Therefore, efforts are needed to balance these risks with potential improvements in local control.

In the era of IMRT, dose-escalation continues to be under investigation for patients with locally advanced disease [79]. A 2014 review of IMRT developed a linear quadratic dose-response model, suggesting that for IMRT-treated patients with anal cancer, a >5 Gy increase in dose may improve local control rates by $>10 \%$ [80]. Despite potential gains in treatment efficacy associated with dose escalation, increased doses must still be weighed against late toxicities of higher doses [74]. The ongoing ACT V trial, discussed later in this review, will assess dose escalation for patients with T3-T4 disease [76].

\section{Intensity-Modulated Radiation Therapy: RTOG 05-29}

Earlier randomized trials for anal cancer (ACTI to ACT II) relied on older radiation techniques using 2-4 fields that provide substantial radiation doses to organs at risk nearby the target volume [47]. IMRT, which modulates radiation intensity in a given field often with nine or more fields, allows delivery of more conformal dose, facilitating coverage of the clinical target with reduction of dose to surrounding normal organs at risk, possibly resulting in fewer treatment breaks and decreased overall treatment time $[53,68]$. Various retrospective and small prospective series demonstrated reductions in gastrointestinal and skin toxicity with the use of IMRT relative to the MMC arm of RTOG 98-11, where patients were treated with 2-dimensional or 3-dimensional conformal radiotherapy (3DCRT, Figure 1) [79,81-92]. Several institutional series compared patients treated with 
3DCRT and IMRT and also demonstrated improved dermatologic and gastrointestinal toxicities, with comparable disease-specific outcomes compared to the MMC arm of RTOG 98-11 [85,93-98].
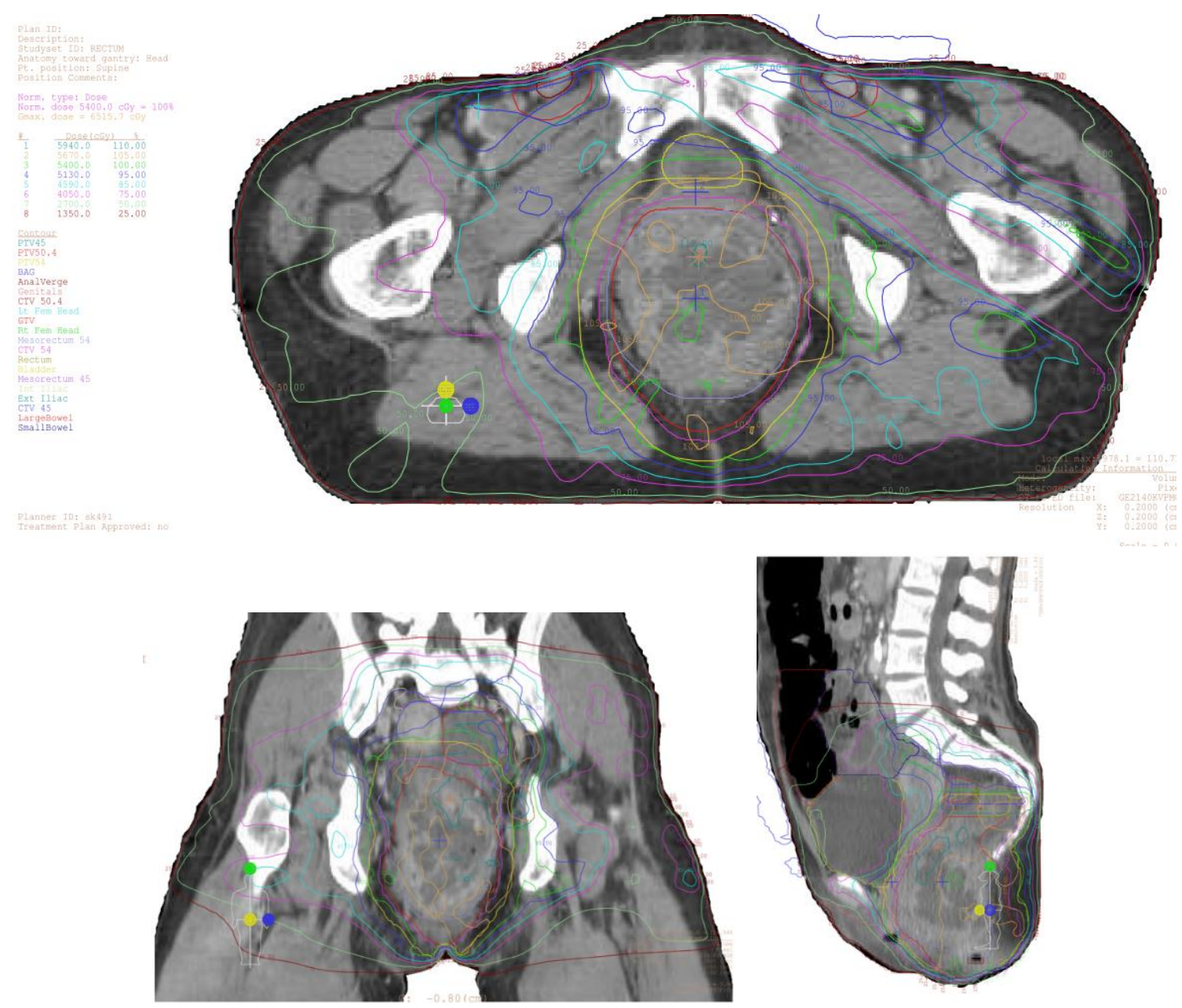

Figure 1. Example of 3DCRT photon plan for a patient with localized anal cancer. The primary tumor involved lymph nodes, and elective nodes were treated to $54 \mathrm{~Gy}, 50.4 \mathrm{~Gy}$, and $45 \mathrm{~Gy}$ in 30 fractions, respectively.

Therefore, concurrent dose-painted IMRT and 5FU/MMC with chemotherapy was prospectively evaluated with RTOG 05-29 [53]. The study's primary endpoint was a reduction of $15 \%$ in gastrointestinal and genitourinary toxicities compared to the treatment strategy employed in RTOG 98-11 [7,53,59]. Patients in RTOG 05-29 with T2N0 disease received 50.4 Gy tumor PTVs and 45 Gy elective nodal irradiation; patients with T3-4N0-3 disease received $54 \mathrm{~Gy}$ to the tumor PTV, $50.4 \mathrm{~Gy}$ for $<3 \mathrm{~cm}$ metastatic nodes or $54 \mathrm{~Gy}$ for $>3 \mathrm{~cm}$ metastatic nodes, and $45 \mathrm{~Gy}$ to electively treated nodes [53].

Dose-painted IMRT was associated with reduced $3+$ gastrointestinal and genitourinary toxicities ( 22 vs. $36 \%, p=0.014$ ) and reduced grade $3+$ dermatologic toxicity ( 20 vs. $47 \%, p<0.001$ ) compared to the MMC arm in RTOG 98-11. Patients in RTOG 05-29 also had shorter median treatment duration (43 days vs. 49 days, $p<0.001)$ and shorter median duration of toxicity-related treatment breaks ( 0 vs. 3 days, $p<0.001)$ compared to historical controls.

As RTOG 05-29 assessed treatment toxicity as a primary endpoint, two recent series from the US and Italy report oncologic outcomes experienced by patients treated per RTOG 05-29 [99,100]. A US series of 99 patients with dose-painted IMRT according to RTOG 0529 dosing guidelines and found that at a median follow-up of 49 months, $92 \%$ of the cohort experienced a clinical complete response [99]. Of these 99 patients, 15 underwent 
colostomy, 11 underwent APRs, and 13 eventually developed local recurrence; overall survival at 4 years was $85.8 \%$, and event-free survival at 4 years was $75.5 \%$ [99]. Overall, $20 \%$ of patients experienced grade 3 acute and $15 \%$ experienced grade $2+$ late toxicities [99]. Similarly, a study in Italy reported outcomes of 87 patients treated according to the RTOG 05-29 protocol [100]. At 3 years, rates of local control, disease-free survival, and overall survival were $69 \%, 71 \%$, and $79 \%$, respectively; $15.1 \%$ underwent colostomy at 24 months and $16.4 \%$ experienced cancer-specific mortality at 36 months [100]. Another European multicenter series retrospectively assessed 190 patients with anal cancer who received concurrent chemoradiation with either simultaneous integrated boost IMRT or 3D conformal RT and sequential boost, which involved progressive boost to selected target regions with macroscopic disease [101]. There were no significant differences in cancer-free survival and overall survival between groups [101]. Along with RTOG 05-29, these findings established IMRT in the treatment of anal cancer.

\section{Improvements in Radiotherapy Simulation}

Radiation treatment simulation should involve attention to a patient's prior rectal, gynecologic, and inguinal node exams, as well as careful consideration of a patient's imaging and patient factors such as comfort to treatment position [68]. Although the prone position on a belly board is preferred due to bowel sparing, it comes at the cost of inter-treatment variation and may be affected by the patient's anatomy and degree of bladder filling [102]. Distention of the bladder may be employed with the belly board to facilitate bowel sparing [103]. Immobilization devices such as Vac-Lok cradles, vaginal dilators, and anal markers or wires may also improve simulation and reproducibility [104]. Furthermore, the use of bolus for patients with peri-anal skin involvement, as was done in RTOG 05-29 [53], may be obviated if techniques such as volumetric arc therapy (VMAT) are used [105]. Intravenous and oral contrast may also aid the delineation of organs at risk [106].

\section{Treatment Planning and Delivery: Institutional Practice and Recent Advances}

The use of PET-CT and MRI-CT fusion-based planning have allowed improvements in target delineation and avoidance of organs at risk [107]. RTOG 05-29, which established the feasibility of IMRT, was designed with generous clinical and planning target expansion to ensure adequate tumor coverage [53]. At our institution, image-guided radiation therapy often allows the use of tighter margins. We employ CTV of the primary tumor and anal canal with $1.0-1.5 \mathrm{~cm}$ margins radially and $2.5 \mathrm{~cm}$ margins superiorly. We also use a $0.7 \mathrm{~cm}$ PTV expansion.

Per RTOG guidelines, radiation doses are based on patients' staging: patients with T2N0 disease received 42 Gy elective nodal and 50.4 Gy anal tumor PTVs in 28 fractions, and patients with T3-4N0-3 disease received 45 Gy elective nodal and $50.4 \mathrm{~Gy}<3 \mathrm{~cm}$ or $54 \mathrm{~Gy}>3 \mathrm{~cm}$ metastatic nodal and $54 \mathrm{~Gy}$ anal tumor PTVs in 30 fractions. Although data from other institutions make use of sequential boost strategies with IMRT doses up to 59.4 as in RTOG 98-11 [49], at our institution, patients are treated with dose-painted IMRT in accordance with RTOG 05-29.

At our institution, inguinal lymph node biopsies are not routinely used to pathologically assess nodal involvement. If nodes demonstrate tumor involvement on PET/CT or other imaging, clinically involved nodes are treated to $50.4 \mathrm{~Gy}$ for nodes $<3 \mathrm{~cm}$ or to $54 \mathrm{~Gy}$ for nodes $>3 \mathrm{~cm}$. Although some studies, including RTOG 05-29 recommend radiating involved nodal regions to $50.4 \mathrm{~Gy}$ and $54 \mathrm{~Gy}$, our institutional practice treats uninvolved nodes electively to $45 \mathrm{~Gy}$.

The development of various contouring atlases has also aided the standardization of contouring techniques [108-111]. Amongst normal structures, we recommend contouring large bowel, small bowel, femoral heads, iliac bones, bladder, perianal skin, and genitalia. We recommend maximizing PTV with $>90 \%$ of the primary tumor and involved nodes receiving prescription dose coverage, and with $>85 \%$ of elective nodal PTVs receiving 
the prescription dose. We recommend correction for tissue heterogeneity. Treatment is delivered once daily with five fractions per week, with daily image guidance for prone treatment delivery.

Although our institution uses RTOG 05-29 dose constraints, adequate target coverage is often challenging without exceeding OAR dose-volume constraints. Doing so is particularly difficult for patients with large tumors or patients with large proportions of small bowel in the treatment field.

Improvements in treatment may also be afforded by VMAT, image-guided, MRIbased, and adaptive planning. Rotational techniques such as VMAT reduce treatment time compared to static IMRT (Figure 2) [112-116]. IMRT and image-guided radiotherapy with daily imaging and adaptive planning may also decrease the dose delivered to major OARs $[68,112]$. Advances in adaptive planning, involving adjustments of radiation plan based on patient-specific changes during the course of treatment, make use of cone-beam $\mathrm{CT}$ adjusted as the tumor shrinks. PET- and MRI-based planning may improve target delineation, although in our institutional practice, baseline MRI imaging is usually only obtained if there is a concern for T4 disease. Further studies are needed to evaluate adaptive planning and other techniques with reference to accepted IMRT techniques $[53,68]$.

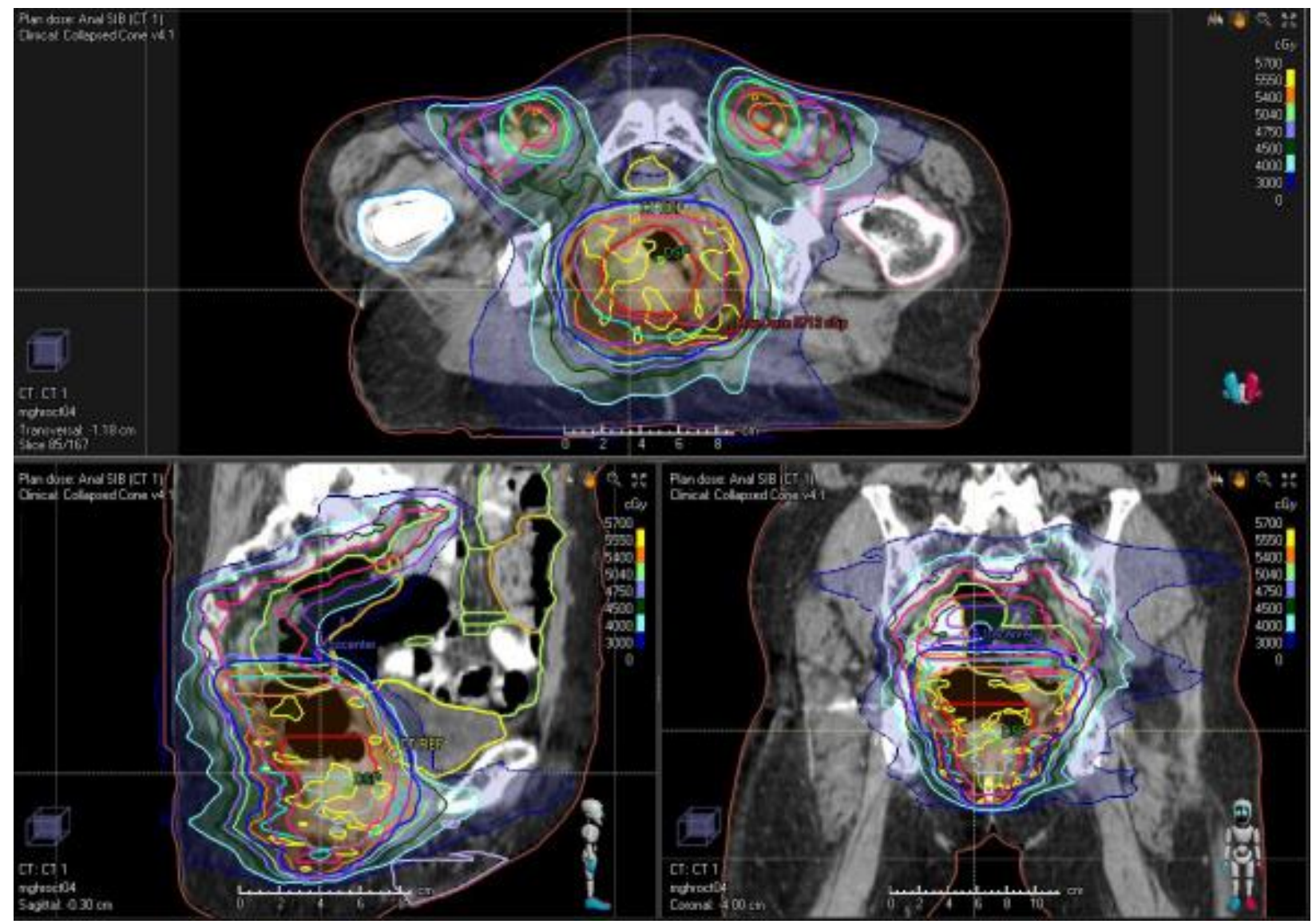

Figure 2. Example of VMAT photon plan for a patient with clinically staged T2N1 anal cancer. The primary tumor and mesorectum, involved lymph node, and elective nodes were treated to $54 \mathrm{~Gy}, 50.4 \mathrm{~Gy}$, and $45 \mathrm{~Gy}$ in 30 fractions, respectively.

\section{Hematologic and Genitourinary Toxicity: Implications for Treatment Planning}

Advances are also being made in hematologic toxicity amongst patients receiving chemoradiation for anal cancer. A recent study categorized total pelvic bone marrow into 3 subsites (lumbosacral bone marrow, including the entire sacrum and L5 vertebral body; iliac bone marrow extending from the iliac crests to the superior border of the femoral head; and lower pelvic bone marrow, including the pubic bones, ischia, acetabula, and proxi- 
mal femurs) and used a generalized linear model to assess the correlation between the equivalent uniform dose to individual pelvic subsites and hematologic outcomes [117]. The analysis suggests that radiation to lumbosacral bone marrow, total pelvic bone marrow, and iliac bone marrow were individually associated with hematologic toxicity [117]. Another study found that treatment of the pelvic bone marrow to a mean dose of $\geq 30 \mathrm{~Gy}$ was associated with a 14-fold increase in the odds of developing grade $3+$ hematologic toxicity (compared to $<30 \mathrm{~Gy}$ ), supporting the role of mean dose to the pelvic bone marrow as a useful predictor for hematologic toxicity [118]. A retrospective study suggested that smaller volumes of the pelvic bone marrow were correlated with lower 3-week blood counts [119]. Sparing $\geq 750 \mathrm{cc}$ of pelvic bone marrow from doses of $\geq 30 \mathrm{~Gy}$ was associated with $0 \%$ grade $3+$ leukopenia or neutropenia at week 3; furthermore, higher V40 Gy to the lower pelvic bone marrow was associated with cytopenia [119]. The authors suggest that sparing a critical marrow reserve and limiting lower pelvis V40 may reduce hematologic toxicity risk [119].

Recent studies have also reported efforts to mitigate hematologic toxicity through selective avoidance of bone marrow with ${ }^{18}$ FDG-PET guidance [120,121]. In a study of ten patients with locally advanced anal cancer, Franco et al. outlined pelvic bone marrow defined as either the whole outer contour of pelvic bones or as active bone marrow identified using ${ }^{18}$ FDG-PET. The authors demonstrate a degree of reduction in dose to active pelvic bone marrow defined using ${ }^{18}$ FDG-PET compared to optimization using iliac crests per RTOG 05-29, mirroring the reduction in dose when accounting for pelvic bone marrow outlined by the outer surface of external bony structures [120]. A single-arm prospective phase II study evaluated ${ }^{18}$ FDG-PET and found that ${ }^{18}$ FDG-PET-guided IMRT with bone marrow sparing was associated with a reduction in acute hematologic toxicity (19\% experienced $\geq$ G3 acute hematologic toxicity) [121]. These findings are exciting as they suggest further means through which hematologic toxicities may be reduced in patients with anal cancer; efforts are needed to identify patient populations most likely to benefit from the incorporation of ${ }^{18}$ FDG-PET in IMRT planning [120,121].

A retrospective cohort of 95 women with anal cancer assessed the incidence of vaginal stenosis after definitive chemoradiation. The study demonstrated $21.4 \%$ with grade 0 vaginal stenosis, $14.3 \%$ with grade 1, 27.1\% with grade 2, and 37.1\% with grade 3 [122]. Younger age, greater tumor dose, and earlier treatment year were associated with a higher grade of vaginal stenosis [122]. Furthermore, current atlas-defined female sexual organs at risk do not specifically include the clitoris, and the impact of radiotherapy on the clitoris and late sexual toxicity is poorly understood [123]. Recent evidence supports the feasibility of contouring the anatomically accurate clitoris on standard planning imaging and demonstrates that clitoris-sparing vs. standard IMRT can reduce clitoral dose, suggesting possible safe reduction in sexual toxicity compared to standard IMRT [123].

Notably, the prospective DILANA trial is designed to evaluate the incidence and grade of vaginal fibrosis and to reduce vaginal wall dose in women receiving IMRT for anal cancer. DILANA will randomize patients to two arms that differ only in the diameter of the tampon used during treatment and will assess the incidence and grate of vaginal fibrosis 12 months after chemoradiation [124].

\section{Timing of Treatment Evaluation and Persistent/Recurrent Disease}

Full regression of anal cancer often takes weeks to months after the completion of chemoradiotherapy; follow-up usually entails assessment at four-week intervals using digital rectal exam and anoscopy at 3 months after completion of therapy. Biopsy is used in patients with residual disease at 6 months or progressive tumor at any time.

In RTOG 87-04, treatment response was evaluated with biopsies 6 weeks after therapy. In their cohort, $12.0 \%$ had positive biopsy results [48]. Salvage chemoradiotherapy consisted of a radiation boost to an additional $9 \mathrm{~Gy}$ to the region of residual disease and one dose of 5FU and cisplatin. Of patients who received salvage chemoradiotherapy, 
complete response was achieved in 55\%; it was uncertain whether patients treated with salvage chemoradiotherapy were slow or nonresponders [48].

Slow response to chemoradiotherapy may lead some patients to have unnecessary surgery. A post-hoc analysis of patients in ACT II suggests that many patients who do not experience a clinical complete response at 11 weeks after treatment eventually respond by 26 weeks [125]. In this post hoc analysis, of those who underwent assessments at 11 weeks, 18 weeks, and 26 weeks after completion of primary treatment, complete response was achieved in $52 \%$ at week $11,71 \%$ at week 18 , and $78 \%$ at week 26 [125]. Among patients who completed all 3 assessments, rates of 5-year overall survival of patients who achieved complete response at 11 weeks, 18 weeks, and 26 weeks were 85\% (95\% CI, 81-88\%), 86\% $(95 \%, 82-88 \%)$, and $87 \%(95 \%$ CI, $84-90 \%)$, respectively, supporting assessment at 26 weeks post-chemoradiotherapy but also highlighting the length of time some patients may need to achieve complete response [125].

\section{Treatment of Persistent/Recurrent Disease}

Despite generally good outcomes after primary chemoradiation without surgery for primary anal cancer, consistent with the ACT II results [125], studies demonstrate persistent disease in $10-15 \%$ of patients $[28,126-128]$. The primary treatment for persistent disease is APR [129]. In the UKCCCR trial comparing chemoradiotherapy vs. radiotherapy alone, patients who experienced $<50 \%$ response underwent salvage APR, of whom $60 \%$ were free of locoregional recurrence [44]. In RTOG 87-04, after salvage chemoradiotherapy, 9 of 10 patients with persistent disease underwent APR, of whom 6 recurred [48].

Furthermore, among patients who received primary chemoradiotherapy for anal cancer, multiple retrospective series show that $10-30 \%$ of patients may experience recurrent disease $[72,128]$. Similar to persistent disease, salvage APR is a potentially curative option for locally recurrent anal cancer with 5-year overall survival of 40-60\% [69,128,130-132]. Other series report survival of over $80 \%$ [128,133-136].

Efforts have been made to identify differences in outcome comparing persistent vs. recurrent disease [128]. Although some studies demonstrate no survival difference among patients who receive salvage APR for persistent vs. recurrent disease $[135,137,138]$, others suggest that persistent disease or early recurrence may be associated with worse outcomes, possibly due to more aggressive tumor biology in persistent disease or early recurrence $[132,133,139,140]$. Innovations in surgical technique for APR may improve outcomes [131]. However, surgical morbidity is high, and wound complications occur in upwards of $80 \%$ in some series [141,142]. Systemic therapy remains the standard of care for unresectable recurrent disease, with ongoing efforts to identify regimens that can improve outcomes [143-149].

Treatment of locally recurrent anal cancer with external beam re-irradiation and/or intra-operative radiotherapy (IORT) is merits further study [128]. A cohort of 10 patients with locally recurrent anal cancer who received at least $30 \mathrm{~Gy}$ to the primary lesion received an additional 27-45 Gy re-irradiation for recurrent disease [150]. Three patients who received re-irradiation without surgery were disease-free at a median of 84 months' followup, and of five patients who received re-irradiation and subsequent surgery, three were disease-free at a median of 43 months' follow-up [150].

At our institution, IMRT and/or proton radiotherapy are considered when re-irradiating locally recurrent disease, with treatment delivered to gross disease only [128]. A report of patients with locally recurrent anal cancer treated with IORT found that although 50\% demonstrated positive resection margins, fewer than a quarter experienced recurrence within the IORT treatment field, suggesting a benefit from IORT [129]. Another study of 14 patients with locally recurrent anal cancer who received salvage surgery and IORT did not find evidence of improved survival or local control associated with IORT [151]. Further work is needed to clarify treatment strategies in the setting of locally recurrent disease. 


\section{Proton Therapy in Anal Cancer}

There has been growing interest in the potential for proton RT to decrease the risk of acute and late adverse effects associated with treatment. Proton therapy facilitates delivery of energy at defined depths, allowing low entry dose and minimal exit dose, theoretically decreasing treatment adverse effects $[152,153]$. Various retrospective series and dosimetric studies suggest that protons can decrease hematologic toxicity in patients with gastrointestinal cancers, which may benefit patients with anal cancer undergoing concurrent chemotherapy [54,152,154-156]. Notably, dosimetric analyses suggest pencil beam scanning proton therapy may improve dose delivery and improve sparing of nontarget structures compared to IMRT and 3DCRT (Figure 3) [54,155].

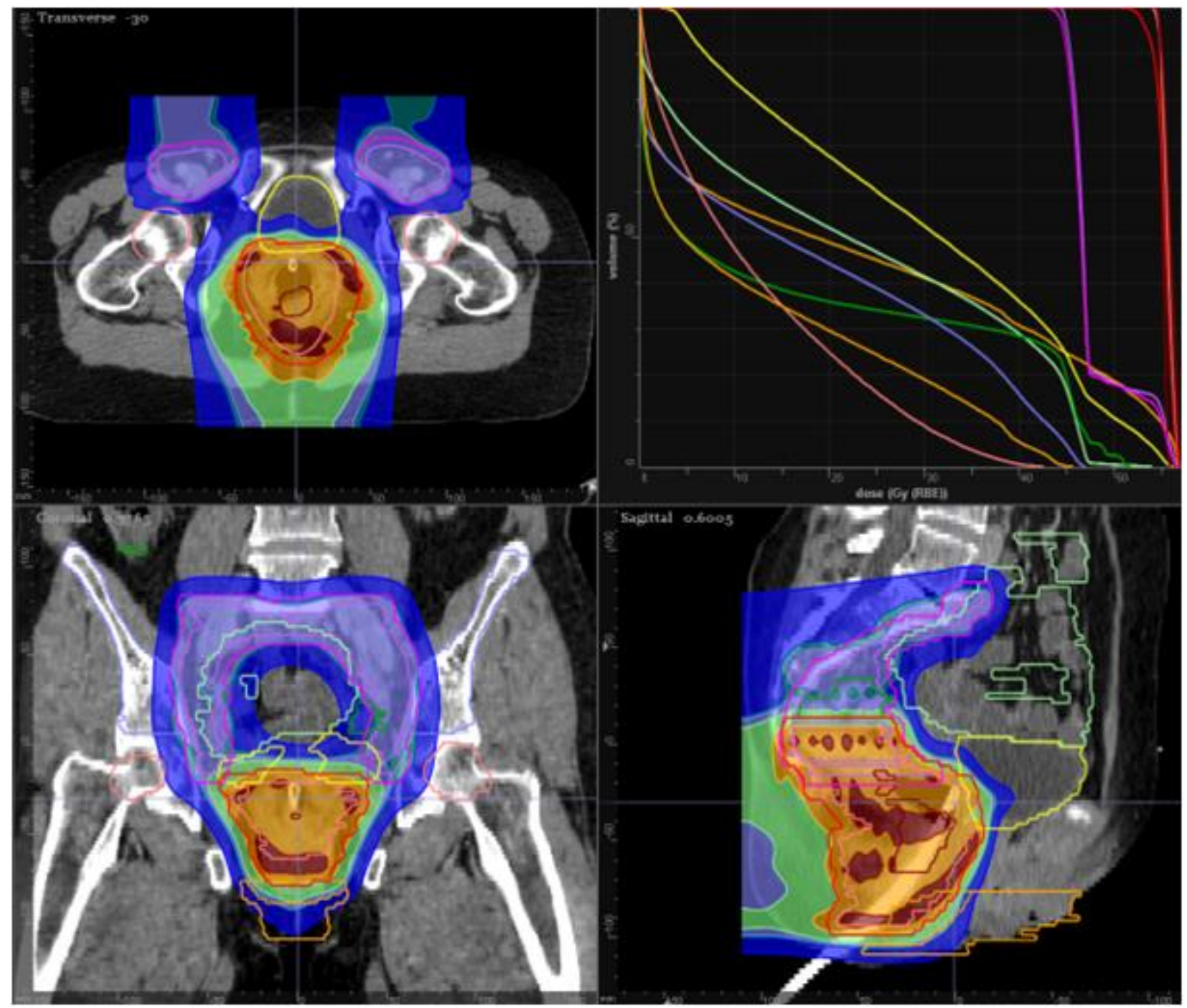

Figure 3. Example of pencil beam scanning proton plan for patient with early stage anal cancer. Elective inguinal nodes were treated with an AP field to $42 \mathrm{~Gy}$. Elective upper pelvic nodes were treated to $45 \mathrm{~Gy}$. Primary tumor and mesorectum treated to 50.4 Gy in 28 fractions.

A recent multi-institutional prospective feasibility study assessed concurrent chemoradiation with pencil beam scanning proton therapy with 5FU and MMC in patients with clinical T1-4, N0-3 anal cancer [54]. The rate of grade 3+ radiation dermatitis in the study cohort was $24 \%$, compared to $48 \%$ in RTOG 98-11 [59]; the 2-year rate of overall complete response was $88 \%$ [54]. These data support the feasibility of pencil beam scanning proton therapy for anal cancer. An ongoing study is assessing linear energy transfer-optimized intensity modulated proton therapy (LET-IMPT) with cisplatin and 5FU, with primary end- 
point defined as physician-reported grade 3+ gastrointestinal, genitourinary, and hematologic toxicity (NCT03690921). Another ongoing trial is assessing proton beam radiotherapy (50.4-54 Cobalt Gray Equivalent [CGE] in 28-30 fractions), with primary outcome defined as 3-month grade 3+ hematologic, gastrointestinal, genitourinary, and dermatologic toxicity (NCT03018418). At our institution, we also consider protons to minimize toxicity in the setting of re-irradiation for persistent/recurrent disease [128].

\section{Ongoing Trials and Studies in Development: PLATO (ACT III, IV, V)}

Newer trials are attempting to elucidate ways in which therapy can be further personalized for each patient. Because more advanced lesions (T3-4 and node-positive) have higher rates of treatment failure, the United Kingdom's Personalising Anal Cancer Radiotherapy Dose (PLATO) trial portfolio, which includes ACT III, ACT IV, and ACT V, examines riskadapted therapy and stratifies early-stage and late-stage disease [76]. The trials have as their primary endpoint rates of 3-year locoregional failure.

As the Nigro protocol demonstrated effective control of early-stage disease with doses as low as 30 Gy [22], the nonrandomized phase II study ACT III will evaluate dosereduced chemoradiotherapy in patients who underwent local excision and were found to have T1N0 disease. Patients with $>1 \mathrm{~mm}$ margin will undergo observation and patients with $\leq 1 \mathrm{~mm}$ margin will be treated with chemoradiotherapy (41.4 Gy in 23 fractions with capecitabine) [157].

In the phase II ACT IV study of patients with intermediate-risk disease, patients with cT1-T2 $(\leq 4 \mathrm{~cm})$ node negative disease will be randomized to the standard radiation arm of $50.4 \mathrm{~Gy}$ in 28 fractions or the dose de-escalated arm of $41.4 \mathrm{~Gy}$ in 23 fractions. ACT IV will assess if similarly excellent rates of locoregional control with lower rates of adverse effects are achievable with the de-escalated dose [157].

Lastly, the phase II/III ACT V trial, which includes patients with locally advanced disease with tumors $>4 \mathrm{~cm}$ or positive nodes, will evaluate radiation dose escalation to 53.2 Gy, 58.8 Gy, or 61.6 Gy (28 fractions for all, with standard concurrent chemotherapy), comparing rates of local control and adverse effects. During interim analysis, one of the dose-escalated arms (58.8 Gy or 61.6 Gy) will proceed to phase III. Targeted agents in combination with chemoradiotherapy are also being assessed [158-160], as well as vaccine therapy targeted at cells infected with HPV [161,162].

\section{Immuno-oncology in the High-Risk and Metastatic Setting}

Although the majority of patients with anal cancer are treated curatively with chemoradiation, approximately $25 \%$ develop distant metastases $[163,164]$. Historically, these patients were commonly treated with doublet chemotherapy with cisplatin and fluorouracil, based on small retrospective series [165]. Given the association between anal cancer and immunogenic HPV oncoproteins, and tumoral expression of PD-L1 that mitigates the antitumor immune response [166,167], a recent study therefore assessed the role of nivolumab, an anti-PD-1 monoclonal antibody, in patients with metastatic anal cancer [55]. The phase II trial found that of 37 patients who received at least one dose of nivolumab, 9 (24\%) demonstrated tumor response, of whom 2 experienced complete response [55].

An ongoing phase III trial is assessing the role of nivolumab after combined modality therapy among patients with high-risk stage II-IIIB anal cancer (NCT03233711). Patients will be randomized to up to 6 months of adjuvant nivolumab vs. observation after combined modality therapy, with the primary endpoint of disease-free survival. Ongoing trials assessing radiotherapy regimens, proton therapy, and immune-oncology are summarized in Table 2. 
Table 2. Ongoing Trials.

\begin{tabular}{|c|c|c|c|}
\hline Trial/NCT ID & Inclusion & Design & Treatments \\
\hline \multicolumn{4}{|c|}{ RT dose escalation vs. de-escalation } \\
\hline ECOG-DECREASE [75] & T1-2N0M0 & $\begin{array}{l}\text { Randomized phase II: } \\
\text { standard-dose CRT vs. } \\
\text { de-intensified CRT }\end{array}$ & $\begin{array}{l}28 \text { fractions vs. de-intensified } 20-23 \text { fractions } \\
\text { of IMRT with MMC and 5FU or capecitabine } \\
\text { Standard: } \\
\text { T1-T2 N0: } 50.4 \text { Gy to primary tumor with } \\
42 \text { Gy to elective nodal regions, all in } \\
28 \text { fractions } \\
\text { De-intensified: } \\
\text { T1 N0: } 36 \text { Gy to primary tumor with } 32 \text { Gy } \\
\text { to elective nodal regions, all in } 20 \text { fractions } \\
\text { T2 N0: } 41.4 \text { Gy to primary tumor with } \\
34.5 \text { Gy to elective nodal regions, all in } \\
23 \text { fractions }\end{array}$ \\
\hline ACT III $[76,157]$ & T1N0 & $\begin{array}{l}\text { Single-arm phase II: dose } \\
\text { reduced CRT }\end{array}$ & $\begin{array}{l}\text { No RT for }>1 \mathrm{~mm} \text { margin; for }<1 \mathrm{~mm} \\
\text { margin, } 41.4 \mathrm{~Gy} \text { in } 23 \text { fractions }\end{array}$ \\
\hline ACT IV [76,157] & T1-2, N0 & $\begin{array}{l}\text { Randomized phase II: standard } \\
\text { chemotherapy (5FU/MMC) and } \\
\text { standard vs. de-intensified RT }\end{array}$ & $\begin{array}{l}\text { Standard RT arm of } 50.4 \mathrm{~Gy} \text { in } 28 \text { fractions } \\
\text { or de-intensified radiation arm of } 41.4 \mathrm{~Gy} \text { in } \\
23 \text { fractions }\end{array}$ \\
\hline ACT V $[76,157]$ & T3-4, N0-X & $\begin{array}{l}\text { Randomized phase II/III: } \\
\text { Standard chemotherapy } \\
\text { (5FU/MMC) with standard vs. } \\
2 \text { escalated radiation doses }\end{array}$ & $\begin{array}{l}53.2 \mathrm{~Gy}, 58.8 \mathrm{~Gy} \text {, or } 61.6 \mathrm{~Gy} \text { all in } 28 \text { fractions } \\
\text { with standard concurrent chemo. One of the } \\
\text { dose-escalation arms will proceed to } \\
\text { phase III }\end{array}$ \\
\hline
\end{tabular}

Proton therapy

NCT03690921 (MDACC) Non-metastatic disease

NCT03018418 (Cincinnati) T2-4 disease with any N
Single-arm phase II trial assessing adverse effects of proton RT and standard chemotherapy (cisplatin and $5 \mathrm{FU})$

Prospective pilot study evaluating the feasibility of intensity-modulated proton therapy in reducing RT toxicity

\section{NCT04462042 (Umeå \\ University/Sweden) \\ T2 (>4 cm)-4, N0-1c, M0}

Open label, multi-center, randomised phase II study, comparing proton to photon RT

Linear energy transfer (LET)-optimized intensity-modulated proton therapy (IMPT)

Primary target volume 50.4-54 CGE in 28-30 fractions; nodal volumes 42-54 CGE in 28-30 fractions, with 5FU and MMC

Photon: primary tumor and nodal metastases $>2 \mathrm{~cm} 57.5$ Gy in 27 fractions (VMAT/IMRT/tomotherapy); nodal metastases up to $2 \mathrm{~cm}$ will receive $50.5 \mathrm{~Gy}$ in 27 fractions; elective nodes will receive 41.6 Gy

Proton: spot scanning, total dose to the primary tumor target and node metastases $>2 \mathrm{~cm}$ is $57.5 \mathrm{~Gy}(\mathrm{RBE})$ in 27 fractions; nodal metastases up to $2 \mathrm{~cm}$ will receive $50.5 \mathrm{~Gy}(\mathrm{RBE})$ in 27 fractions; elective nodes will receive $41.6 \mathrm{~Gy}(\mathrm{RBE})$

Immuno-oncology

stage IIB (T3N0M0 only), IIIA (T2N1M0), IIIB (T4N0M0), or IIIC (T3N1M0, T4N1M0) invasive squamous cell carcinoma of the anus or anorectum

\begin{tabular}{ll}
\hline NCT02919969 & $\begin{array}{l}\text { Metastatic anal cancer with no } \\
\text { limitations to prior treatment }\end{array}$ \\
\hline & $\begin{array}{l}\text { Unresectable locally } \\
\text { advanced, recurrent, or } \\
\text { metastatic squamous cell anal } \\
\text { carcinoma }\end{array}$ \\
\hline & Locally advanced disease (IIB: \\
NCT04230759 & T3N0M0; IIIA: T1-2N1M0; \\
(RADIANCE trial) & TIIB T4N0M0; IIIC: \\
& T3-4N1M0; T2 > 4 cm Nany)
\end{tabular}

Randomized phase III trial of nivolumab after combined modality therapy
Up to 6 months of nivolumab IV vs. up to 6 months of observation

\begin{tabular}{ll}
$\begin{array}{l}\text { Phase II study of } \\
\text { pembrolizumab }\end{array}$ & $\begin{array}{l}\text { Pembrolizumab } 200 \mathrm{mg} \text { IV infusion every } \\
3 \text { weeks }\end{array}$ \\
\hline
\end{tabular}

mDCF (docetaxel, cisplatin, $5 \mathrm{FU}$ ) with vs. without atezolizumab

Phase II trial assessing the efficacy of durvalumab in combination with CRT with $\mathrm{MMC}+5 \mathrm{FU}$
8 cycles of mDCF with vs. without MPDL3280A (atezolizumab) for 12 months

53.2-58.9 Gy with nodal and elective nodal irradiation, with $\mathrm{MMC}+5 \mathrm{FU}$, with vs. without 12 doses of durvalumab 
Table 2. Cont.

\begin{tabular}{|c|c|c|c|}
\hline Trial/NCT ID & Inclusion & Design & Treatments \\
\hline NCT03944252 & $\begin{array}{l}\text { Progression on or after } \\
\text { first-line systemic therapy for } \\
\text { surgically unresectable or } \\
\text { metastatic disease }\end{array}$ & $\begin{array}{l}\text { Randomized Phase II trial of } \\
\text { cetuximab and avelumab or } \\
\text { avelumab alone for } \\
\text { unresectable, locally advanced, } \\
\text { or metastatic anal cancer } \\
\text { progressed after at least one line } \\
\text { of systemic therapy }\end{array}$ & $\begin{array}{l}\text { Avelumab IV with vs. without cetuximab, } \\
\text { given until progression of disease }\end{array}$ \\
\hline NCT04444921 & $\begin{array}{l}\text { Inoperable, recurrent, or } \\
\text { metastatic disease }\end{array}$ & $\begin{array}{l}\text { Randomized phase III trial of } \\
\text { nivolumab with chemotherapy } \\
\text { in treatment-naive metastatic } \\
\text { anal cancer }\end{array}$ & $\begin{array}{l}\text { Carboplatin and paclitaxel with vs. without } \\
\text { nivolumab }\end{array}$ \\
\hline NCT01285778 & $\mathrm{T} 2-4$, any $\mathrm{N}$ & $\begin{array}{l}\text { Phase II assessing the efficacy } \\
\text { and toxicity of radiotherapy } \\
\text { with } 5 \text { FU, MMC, and } \\
\text { panitumumab }\end{array}$ & $\begin{array}{l}\text { Radiation therapy will be administered } \\
\text { concurrent with chemotherapy and } \\
\text { panitumumab treatment (IV over } 8 \text { weeks) }\end{array}$ \\
\hline $\begin{array}{l}\text { NCT04472429 } \\
\text { (POD1UM-303/InterAACT 2) }\end{array}$ & $\begin{array}{l}\text { Inoperable locally recurrent } \\
\text { or metastatic SCAC with no } \\
\text { prior systemic therapy other } \\
\text { than chemotherapy } \\
\text { administered with } \\
\text { radiotherapy as a } \\
\text { radiosensitizer }\end{array}$ & $\begin{array}{l}\text { Phase III double-blind } \\
\text { randomized trial of } \\
\text { carboplatin-paclitaxel with } \\
\text { Retifanlimab or placebo in } \\
\text { patients with inoperable locally } \\
\text { recurrent or metastatic disease } \\
\text { with no prior systemic } \\
\text { chemotherapy }\end{array}$ & $\begin{array}{l}\text { Carboplatin, paclitaxel, and either placebo } \\
\text { or retifanlimab }\end{array}$ \\
\hline
\end{tabular}

\section{Conclusions}

Advances in radiotherapy for anal cancer have put chemoradiation at the forefront of primary management for this disease. The advent of IMRT has improved our ability to deliver a conformal dose, affording excellent rates of local tumor control while minimizing adverse effects. Nevertheless, efforts are needed to ascertain doses and treatment delivery strategies that can further improve local control while minimizing toxicity. The results of studies assessing dose schedules that vary based on the extent of disease as well as other treatment strategies such as VMAT and proton therapy are eagerly awaited.

Author Contributions: Conceptualization, E.C.D., J.D.B. and J.Y.W.; methodology, E.C.D., J.D.B. and J.Y.W.; writing - original draft preparation, E.C.D., J.D.B. and J.Y.W.; writing-review and editing, J.D.B. and J.Y.W.; supervision, E.C.D., J.D.B. and J.Y.W. All authors have read and agreed to the published version of the manuscript.

Funding: No funding was received for this work.

Institutional Review Board Statement: Ethical review and approval were not available as this study is a review of the literature.

Informed Consent Statement: Not applicable.

Data Availability Statement: No new data were created or analyzed in this study. Data sharing is not applicable to this article.

Conflicts of Interest: The authors declare no conflict of interest.

\section{References}

1. NIH National Cancer Institute. Cancer Facts \& Figures 2020. CA. Cancer J. Clin. 2020, 15, 5323-5337.

2. Wilkinson, J.R.; Morris, E.J.A.; Downing, A.; Finan, P.J.; Aravani, A.; Thomas, J.D.; Sebag-Montefiore, D. The rising incidence of anal cancer in England 1990-2010: A population-based study. Color. Dis. 2014, 16, O234-O239. [CrossRef] [PubMed]

3. Palefsky, J.M.; Giuliano, A.R.; Goldstone, S.; Moreira, E.D.; Aranda, C.; Jessen, H.; Hillman, R.; Ferris, D.; Coutlee, F.; Stoler, M.H.; et al. HPV vaccine against anal HPV infection and anal intraepithelial neoplasia. N. Engl. J. Med. 2011, 365, 1576-1585. [CrossRef]

4. Chaturvedi, A.K.; Madeleine, M.M.; Biggar, R.J.; Engels, E.A. Risk of human papillomavirus-associated cancers among persons with AIDS. J. Natl. Cancer Inst. 2009, 101, 1120-1130. [CrossRef] 
5. Goldie, S.J.; Kuntz, K.M.; Weinstein, M.C.; Freedberg, K.A.; Welton, M.L.; Palefsky, J.M. The clinical effectiveness and costeffectiveness of screening for anal squamous intraepithelial lesions in homosexual and bisexual HIV-positive men. J. Am. Med. Assoc. 1999, 281, 1822-1829. [CrossRef]

6. Goldie, S.J.; Kuntz, K.M.; Weinstein, M.C.; Freedberg, K.A.; Palefsky, J.M. Cost-effectiveness of screening for anal squamous intraepithelial lesions and anal cancer in human immunodeficiency virus-negative homosexual and bisexual men. Am. J. Med. 2000, 108, 634-641. [CrossRef]

7. Gunderson, L.L.; Winter, K.A.; Ajani, J.A.; Pedersen, J.E.; Moughan, J.; Benson, A.B.; Thomas, C.R.; Mayer, R.J.; Haddock, M.G.; Rich, T.A.; et al. Long-term update of US GI intergroup RTOG 98-11 Phase III trial for anal carcinoma: Survival, relapse, and colostomy failure with concurrent chemoradiation involving fluorouracil/mitomycin versus fluorouracil/cisplatin. J. Clin. Oncol. 2012, 30, 4344-4351. [CrossRef]

8. Urbute, A.; Rasmussen, C.L.; Belmonte, F.; Obermueller, T.; Prigge, E.S.; Arbyn, M.; Verdoodt, F.; Kjaer, S.K. Prognostic significance of HPV DNA and p16INK4a in anal cancer: A systematic review and meta-analysis. Cancer Epidemiol. Biomarkers Prev. 2020, 29, 703-710. [CrossRef]

9. Franco, P.; Montagnani, F.; Arcadipane, F.; Casadei, C.; Andrikou, K.; Martini, S.; Iorio, G.C.; Scartozzi, M.; Mistrangelo, M.; Fornaro, L.; et al. The prognostic role of hemoglobin levels in patients undergoing concurrent chemo-radiation for anal cancer. Radiat. Oncol. 2018, 13, 83. [CrossRef]

10. Casadei-Gardini, A.; Montagnani, F.; Casadei, C.; Arcadipane, F.; Andrikou, K.; Aloi, D.; Prete, A.A.; Zampino, M.G.; Argentiero, A.; Pugliese, G.; et al. Immune inflammation indicators in anal cancer patients treated with concurrent chemoradiation: Training and validation cohort with online calculator (ARC: Anal Cancer Response Classifier). Cancer Manag. Res. 2019, $11,3631$. [CrossRef] [PubMed]

11. Marshall, D.T.; Thomas, C.R. Carcinoma of the anal canal. Oncol. Rev. 2009, 3, 27-40. [CrossRef]

12. Beahrs, O.H.; Wilson, S.M. Carcinoma of the anus. Ann. Surg. 1976, 184, 422-428. [CrossRef]

13. Pintor, M.P.; Northover, J.M.A.; Nicholls, R.J. Squamous cell carcinoma of the anus at one hospital from 1948 to 1984 . Br. J. Surg. 1989, 76, 806-810. [CrossRef]

14. Boman, B.M.; Moertel, C.G.; O'Connell, M.J.; Scott, M.; Weiland, L.H.; Beart, R.W.; Gunderson, L.L.; Spencer, R.J. Carcinoma of the anal canal, a clinical and pathologic study of 188 cases. Cancer 1984, 54, 114-125. [CrossRef]

15. Singh, R.; Nime, F.; Mittelman, A. Malignant epithelial tumors of the anal canal. Cancer 1981, 48, 411-415. [CrossRef]

16. Schraut, W.H.; Wang, C.-H.; Dawson, P.J.; Block, G.E. Depth of invasion, location, and size of cancer of the anus dictate operative treatment. Cancer 1983, 51, 1291-1296. [CrossRef]

17. Frost, D.B.; Richards, P.C.; Montague, E.D.; Giacco, G.G.; Martin, R.G. Epidermoid cancer of the anorectum. Cancer 1984, 53, 1285-1293. [CrossRef]

18. Grabenbauer, G.G.; Schneider, I.H.F.; Gall, F.P.; Sauer, R. Epidermoid carcinoma of the anal canal: Treatment by combined radiation and chemotherapy. Radiother. Oncol. 1993, 27, 59-62. [CrossRef]

19. Nigro, N.D.; Vaitkevicius, V.K.; Considine, B. Combined therapy for cancer of the anal canal: A preliminary report. Dis. Colon Rectum 1974, 24, 73-75. [CrossRef]

20. Nigro, N.D.; Seydel, H.G.; Considine, B.; Vaitkevicius, V.K.; Leichman, L.; Kinzie, J.J. Combined preoperative radiation and chemotherapy for squamous cell carcinoma of the anal canal. Cancer 1983, 51, 1826-1829. [CrossRef]

21. Nigro, N.D. An evaluation of combined therapy for squamous cell cancer of the anal canal. Dis. Colon Rectum 1984, 27, 763-766. [CrossRef]

22. Leichman, L.; Nigro, N.; Vaitkevicius, V.K.; Considine, B.; Buroker, T.; Bradley, G.; Seydel, H.G.; Olchowski, S.; Cummings, G.; Leichman, C.; et al. Cancer of the anal canal. Model for preoperative adjuvant combined modality therapy. Am. J. Med. 1985, 78, 211-215. [CrossRef]

23. Papillon, J. Radiation therapy in the conservative management of cancers of the low rectum and anal canal. Int. J. Colorectal Dis. 1986, 1, 251-255. [CrossRef]

24. Papillon, J.; Mayer, M.; Montbarbon, J.F.; Gerard, J.P.; Chassard, J.L.; Bailly, C. A new approach to the management of epidermoid carcinoma of the anal canal. Cancer 1983, 51, 1830-1837. [CrossRef]

25. Papillon, J.; Montbarbon, J.F. Epidermoid carcinoma of the anal canal-A series of 276 cases. Dis. Colon Rectum 1987, 30, 324-333. [CrossRef]

26. Enker, W.E.; Heilwell, M.; Janov, A.J.; Quan, S.H.; Magill, G.; Stearns, M.W.; Shank, B.; Learning, R.; Sternberg, S.S. Improved Survival in Epidermoid Carcinoma of the Anus in Association With Preoperative Multidisciplinary Therapy. Arch. Surg. 1986, 121, 1386-1390. [CrossRef]

27. Michaelson, R.A.; Magill, G.B.; Quan, S.H.Q.; Leaming, R.H.; Nikrui, M.; Stearns, M.W. Preoperative chemotherapy and radiation therapy in the management of anal epidermoid carcinoma. Cancer 1983, 51, 390-395. [CrossRef]

28. Nigro, N.D. Multidisciplinary management of cancer of the anus. World J. Surg. 1987, 11, 446-451. [CrossRef]

29. Sischy, B. The use of radiation therapy combined with chemotherapy in the management of squamous cell carcinoma of the anus and marginally resectable adenocarcinoma of the rectum. Int. J. Radiat. Oncol. Biol. Phys. 1985, 1, 1587-1593. [CrossRef]

30. John, M.J.; Flam, M.; Lovalvo, L.; Mowry, P.A. Feasibility of non-surgical definitive management of anal canal carcinoma. Int. J. Radiat. Oncol. Biol. Phys. 1987, 13, 299-303. [CrossRef] 
31. Flam, M.S.; John, M.; Lovalvo, L.J.; Mills, R.J.; Ramalho, L.D.; Prather, C.; Mowry, P.A.; Morgan, D.R.; Lau, B.P. Definitive nonsurgical therapy of epithelial malignancies of the anal canal a report of 12 cases. Cancer 1983, 51, 1378-1387. [CrossRef]

32. Sischy, B.; Doggett, R.L.S.; Krall, J.M.; Taylor, D.G.; Sause, W.T.; Lipsett, J.A.; Seydel, H.G. Definitive irradiation and chemotherapy for radiosensitization in management of anal carcinoma: Interim report on radiation therapy oncology group study no. 8314 . J. Natl. Cancer Inst. 1989, 81, 850-857. [CrossRef]

33. Hughes, L.L.; Rich, T.A.; Delclos, L.; Ajani, J.A.; Martin, R.G. Radiotherapy for anal cancer: Experience from 1979-1987. Int. J. Radiat. Oncol. Biol. Phys. 1989, 17, 1153-1160. [CrossRef]

34. Jin, H.; Pinheiro, P.S.; Callahan, K.E.; Altekruse, S.F. Examining the gastric cancer survival gap between Asians and whites in the United States. Gastric Cancer 2017, 20, 573-582. [CrossRef]

35. Cummings, B.J.; Keane, T.J.; O'Sullivan, B.; Wong, C.S.; Catton, C.N. Epidermoid anal cancer: Treatment by radiation alone or by radiation and 5-fluorouracil with and without mitomycin C. Int. J. Radiat. Oncol. Biol. Phys. 1991, 21, 1115-1125. [CrossRef]

36. John, M.; Pajak, T.; Flam, M.; Hoffman, J.; Markoe, A.; Wolkov, H.; Paris, K. Dose escalation in chemoradiation for anal cancer: Preliminary results of RTOG 92-08. Cancer J. Sci. Am. 1996, 24, 205-211.

37. Doci, R.; Zucali, R.; Bombelli, L.; Montalto, F.; Lamonica, G. Combined chemoradiation therapy for anal cancer: A report of 56 cases. Ann. Surg. 1992, 215, 150-156. [CrossRef]

38. Martenson, J.A.; Lipsitz, S.R.; Lefkopoulou, M.; Engstrom, P.F.; Dayal, Y.Y.; Cobau, C.D.; Oken, M.M.; Hatter, D.G. Results of combined modality therapy for patients with anal cancer (E7283). An eastern cooperative oncology group study. Cancer 1995, 76, 1731-1736. [CrossRef]

39. Martenson, J.A.; Lipsitz, S.R.; Wagner, H.; Kaplan, E.H.; Otteman, L.A.; Schuchter, L.M.; Mansour, E.G.; Talamonti, M.S.; Benson, A.B. Initial results of a phase II trial of high dose radiation therapy, 5-fluorouracil, and cisplatin for patients with anal cancer (E4292): An Eastern Cooperative Oncology Group study. Int. J. Radiat. Oncol. Biol. Phys. 1996, 35, 745-749. [CrossRef]

40. Green, J.P.; Schaupp, W.C.; Cantril, S.T.; Schall, G. Anal carcinoma: Current therapeutic concepts. Am. J. Surg. 1980, 140, 151-155. [CrossRef]

41. James, R.D.; Pointon, R.S.; Martin, S. Local radiotherapy in the management of squamous carcinoma of the anus. Br. J. Surg. 1985, 72, 282-285. [CrossRef] [PubMed]

42. Tannock, I.F. Combined modality treatment with radiotherapy and chemotherapy. Radiother. Oncol. 1989, 16, 83-101. [CrossRef]

43. Cummings, B.; Keane, T.; Thomas, G.; Harwood, A.; Rider, W. Results and toxicity of the treatment of anal canal carcinoma by radiation therapy or radiation therapy and chemotherapy. Cancer 1984, 54, 2062-2068. [CrossRef]

44. Northover, J.M.A.; Arnott, S.J.; Cunningham, D.; Gallagher, J.; Gray, R.; Hardcastle, J.; Houghton, J.; James, R.D.; Lennon, T.A.; Meadows, H.M.; et al. Epidermoid anal cancer: Results from the UKCCCR randomised trial of radiotherapy alone versus radiotherapy, 5-fluorouracil, and mitomycin. Lancet 1996, 348, 1049-1054.

45. Northover, J.; Glynne-Jones, R.; Sebag-Montefiore, D.; James, R.; Meadows, H.; Wan, S.; Jitlal, M.; Ledermann, J. Chemoradiation for the treatment of epidermoid anal cancer: 13-year follow-up of the first randomised UKCCCR Anal Cancer Trial (ACT I). Br. J. Cancer 2010, 102, 1123-1128. [CrossRef] [PubMed]

46. Bartelink, H.; Roelofsen, F.; Eschwege, F.; Rougier, P.; Bosset, J.F.; Gonzalez, D.G.; Peiffert, D.; van Glabbeke, M.; Pierart, M. Concomitant radiotherapy and chemotherapy is superior to radiotherapy alone in the treatment of locally advanced anal cancer: Results of a phase III randomized trial of the European organization for research and treatment of cancer radiotherapy and gastro. J. Clin. Oncol. 1997, 15, 2040-2049. [CrossRef]

47. Ludmir, E.B.; Kachnic, L.A.; Czito, B.G. Evolution and Management of Treatment-Related Toxicity in Anal Cancer. Surg. Oncol. Clin. N. Am. 2017, 26, 91-113. [CrossRef]

48. Flam, M.; John, M.; Pajak, T.F.; Petrelli, N.; Myerson, R.; Doggett, S.; Quivey, J.; Rotman, M.; Kerman, H.; Coia, L.; et al. Role of mitomycin in combination with fluorouracil and radiotherapy, and of salvage chemoradiation in the definitive nonsurgical treatment of epidermoid carcinoma of the anal canal: Results of a phase III randomized intergroup study. J. Clin. Oncol. 1996, 14, 2527-2539. [CrossRef]

49. Ajani, J.A.; Winter, K.A.; Gunderson, L.L.; Pedersen, J.; Benson, A.B.; Thomas, C.R.; Mayer, R.J.; Haddock, M.G.; Rich, T.A.; Willett, C. Fluorouracil, mitomycin, and radiotherapy vs fluorouracil, cisplatin, and radiotherapy for carcinoma of the anal canal: A randomized controlled trial. JAMA J. Am. Med. Assoc. 2008, 299, 1914-1921. [CrossRef]

50. James, R.D.; Glynne-Jones, R.; Meadows, H.M.; Cunningham, D.; Myint, A.S.; Saunders, M.P.; Maughan, T.; McDonald, A.; Essapen, S.; Leslie, M.; et al. Mitomycin or cisplatin chemoradiation with or without maintenance chemotherapy for treatment of squamous-cell carcinoma of the anus (ACT II): A randomised, phase 3, open-label, $2 \times 2$ factorial trial. Lancet Oncol. 2013, 14, 516-524. [CrossRef]

51. Konski, A.; Garcia, M.; John, M.; Krieg, R.; Pinover, W.; Myerson, R.; Willett, C. Evaluation of Planned Treatment Breaks During Radiation Therapy for Anal Cancer: Update of RTOG 92-08. Int. J. Radiat. Oncol. Biol. Phys. 2008, 72, 114-118. [CrossRef] 
52. Peiffert, D.; Tournier-Rangeard, L.; Gérard, J.P.; Lemanski, C.; François, E.; Giovannini, M.; Cvitkovic, F.; Mirabel, X.; Bouché, O.; Luporsi, E.; et al. Induction chemotherapy and dose intensification of the radiation boost in locally advanced anal canal carcinoma: Final analysis of the randomized UNICANCER ACCORD 03 trial. J. Clin. Oncol. 2012, 30, 1941-1948. [CrossRef] [PubMed]

53. Kachnic, L.A.; Winter, K.; Myerson, R.J.; Goodyear, M.D.; Willins, J.; Esthappan, J.; Haddock, M.G.; Rotman, M.; Parikh, P.J.; Safran, H.; et al. RTOG 0529: A phase 2 evaluation of dose-painted intensity modulated radiation therapy in combination with 5-fluorouracil and mitomycin-C for the reduction of acute morbidity in carcinoma of the anal canal. Int. J. Radiat. Oncol. Biol. Phys. 2013, 86, 27-33. [CrossRef] [PubMed]

54. Wo, J.Y.; Plastaras, J.P.; Metz, J.M.; Jiang, W.; Yeap, B.Y.; Drapek, L.C.; Adams, J.; Baglini, C.; Ryan, D.P.; Murphy, J.E.; et al. Pencil Beam Scanning Proton Beam Chemoradiation Therapy With 5-Fluorouracil and Mitomycin-C for Definitive Treatment of Carcinoma of the Anal Canal: A Multi-institutional Pilot Feasibility Study. Int. J. Radiat. Oncol. Biol. Phys. 2019, 105, 90-95. [CrossRef]

55. Morris, V.K.; Salem, M.E.; Nimeiri, H.; Iqbal, S.; Singh, P.; Ciombor, K.; Polite, B.; Deming, D.; Chan, E.; Wade, J.L.; et al. Nivolumab for previously treated unresectable metastatic anal cancer (NCI9673): A multicentre, single-arm, phase 2 study. Lancet Oncol. 2017, 18, 446-453. [CrossRef]

56. Ho, G.Y.; Woodward, N.; Coward, J.I.G. Cisplatin versus carboplatin: Comparative review of therapeutic management in solid malignancies. Crit. Rev. Oncol. Hematol. 2016, 102, 37-46. [CrossRef]

57. Rich, T.A.; Ajani, J.A.; Morrison, W.H.; Ota, D.; Levin, B. Chemoradiation therapy for anal cancer: Radiation plus continuous infusion of 5-fluorouracil with or without cisplatin. Radiother. Oncol. 1993, 27, 209-215. [CrossRef]

58. Gerard, J.P.; Ayzac, L.; Hun, D.; Romestaing, P.; Coquard, R.; Ardiet, J.M.; Mornex, F. Treatment of anal canal carcinoma with high dose radiation therapy and concomitant fluorouracil-cisplatinum. Long-term results in 95 patients. Radiother. Oncol. 1998, 46, 249-256. [CrossRef]

59. Gunderson, L.L.; Winter, K.A.; Ajani, J.A.; Pedersen, J.E.; Benson, A.B.; Thomas, C.R.; Mayer, R.J.; Haddock, M.G.; Rich, T.A.; Willett, C.G. Long-term update of U.S. GI Intergroup RTOG 98-11 phase III trial for anal carcinoma: Comparison of concurrent chemoradiation with 5FU-mitomycin versus 5FU-cisplatin for disease-free and overall survival. J. Clin. Oncol. 2011, $29,367$. [CrossRef]

60. Ben-Josef, E.; Moughan, J.; Ajani, J.A.; Flam, M.; Gunderson, L.; Pollock, J.D.; Myerson, R.; Anne, R.; Rosenthal, S.A.; Willett, C. Impact of overall treatment time on survival and local control in patients with anal cancer: A pooled data analysis of radiation therapy oncology group trials 87-04 and 98-11. J. Clin. Oncol. 2010, 28, 5061-5066. [CrossRef]

61. White, E.C.; Goldman, K.; Aleshin, A.; Lien, W.W.; Rao, A.R. Chemoradiotherapy for squamous cell carcinoma of the anal canal: Comparison of one versus two cycles mitomycin-C. Radiother. Oncol. 2015, 117, 240-245. [CrossRef] [PubMed]

62. Swellengrebel, H.A.M.; Marijnen, C.A.M.; Verwaal, V.J.; Vincent, A.; Heuff, G.; Gerhards, M.F.; Van Geloven, A.A.W.; Van Tets, W.F.; Verheij, M.; Cats, A. Toxicity and complications of preoperative chemoradiotherapy for locally advanced rectal cancer. Br. J. Surg. 2011, 98, 418-426. [CrossRef] [PubMed]

63. Oliveira, S.C.R.; Moniz, C.M.V.; Riechelmann, R.; Alex, A.K.; Braghirolli, M.I.; Bariani, G.; Nahas, C.; Hoff, P.M.G. Phase II Study of Capecitabine in Substitution of 5-FU in the Chemoradiotherapy Regimen for Patients with Localized Squamous Cell Carcinoma of the Anal Canal. J. Gastrointest. Cancer 2016, 47, 75-81. [CrossRef]

64. Glynne-Jones, R.; Meadows, H.; Wan, S.; Gollins, S.; Leslie, M.; Levine, E.; McDonald, A.C.; Myint, S.; Samuel, L.; SebagMontefiore, D. EXTRA-A Multicenter Phase II Study of Chemoradiation Using a 5 Day per Week Oral Regimen of Capecitabine and Intravenous Mitomycin C in Anal Cancer. Int. J. Radiat. Oncol. Biol. Phys. 2008, 72, 119-126. [CrossRef]

65. Allegra, C.J.; Yothers, G.; O'Connell, M.J.; Beart, R.W.; Wozniak, T.F.; Pitot, H.C.; Shields, A.F.; Landry, J.C.; Ryan, D.P.; Arora, A.; et al. Neoadjuvant 5-FU or capecitabine plus radiation with or without oxaliplatin in rectal cancer patients: A phase III randomized clinical trial. J. Natl. Cancer Inst. 2015, 107. [CrossRef] [PubMed]

66. Chong, L.C.; Healey, T.; Michele, T.; Price, T.J. Capecitabine in locally advanced anal cancer, do we need randomised evidence? Expert Rev. Anticancer Ther. 2017, 17, 411-416. [CrossRef] [PubMed]

67. Jones, C.M.; Adams, R.; Downing, A.; Glynne-Jones, R.; Harrison, M.; Hawkins, M.; Sebag-Montefiore, D.; Gilbert, D.C.; Muirhead, R. Toxicity, Tolerability, and Compliance of Concurrent Capecitabine or 5-Fluorouracil in Radical Management of Anal Cancer With Single-dose Mitomycin-C and Intensity Modulated Radiation Therapy: Evaluation of a National Cohort. Int. J. Radiat. Oncol. Biol. Phys. 2018, 101, 1202-1211. [CrossRef]

68. Glynne-Jones, R.; Tan, D.; Hughes, R.; Hoskin, P. Squamous-cell carcinoma of the anus: Progress in radiotherapy treatment. Nat. Rev. Clin. Oncol. 2016, 13, 447-459. [CrossRef] [PubMed]

69. Renehan, A.G.; Saunders, M.P.; Schofield, P.F.; O'Dwyer, S.T. Patterns of local disease failure and outcome after salvage surgery in patients with anal cancer. Br. J. Surg. 2005, 92, 605-614. [CrossRef]

70. Ferrigno, R.; Nakamura, R.A.; Dos Santos Novaes, P.E.R.; Assis Pellizzon, A.C.; Conte Maia, M.A.; Fogarolli, R.C.; Salvajoli, J.V.; Filho, W.J.D.; Lopes, A. Radiochemotherapy in the conservative treatment of anal canal carcinoma: Retrospective analysis of results and radiation dose effectiveness. Int. J. Radiat. Oncol. Biol. Phys. 2005, 61, 1136-1142. [CrossRef]

71. Huang, K.; Haas-Kogan, D.; Weinberg, V.; Krieg, R. Higher radiation dose with a shorter treatment duration improves outcome for locally carcinoma of anal canal. World J. Gastroenterol. 2007, 13, 895. [CrossRef] 
72. Ajani, J.A.; Winter, K.A.; Gunderson, L.L.; Pedersen, J.; Benson, A.B.; Thomas, C.R.; Mayer, R.J.; Haddock, M.G.; Rich, T.A.; Willett, C.G. Prognostic factors derived from a prospective database dictate clinical biology of anal cancer: The intergroup trial (RTOG 98-11). Cancer 2010, 116, 4007-4013. [CrossRef]

73. Gunderson, L.L.; Moughan, J.; Ajani, J.A.; Pedersen, J.E.; Winter, K.A.; Benson, A.B.; Thomas, C.R.; Mayer, R.J.; Haddock, M.G.; Rich, T.A.; et al. Anal carcinoma: Impact of TN category of disease on survival, disease relapse, and colostomy failure in US gastrointestinal intergroup RTOG 98-11 phase 3 trial. Int. J. Radiat. Oncol. Biol. Phys. 2013, 87, 638-645. [CrossRef]

74. Bentzen, A.G.; Guren, M.G.; Vonen, B.; Wanderås, E.H.; Frykholm, G.; Wilsgaard, T.; Dahl, O.; Balteskard, L. Faecal incontinence after chemoradiotherapy in anal cancer survivors: Long-term results of a national cohort. Radiother. Oncol. 2013, 108, 55-60. [CrossRef]

75. Lower-Dose Chemoradiation in Treating Patients With Early-Stage Anal Cancer, the DECREASE Study. Case Med. Res. 2019, 105, 591-605.

76. Smith, C.A.; Kachnic, L.A. Randomized Clinical Trials in Localized Anal Cancer. Surg. Oncol. Clin. N. Am. 2017, 26, 705-718. [CrossRef]

77. Bentzen, A.G.; Balteskard, L.; Wanderås, E.H.; Frykholm, G.; Wilsgaard, T.; Dahl, O.; Guren, M.G. Impaired health-related quality of life after chemoradiotherapy for anal cancer: Late effects in a national cohort of 128 survivors. Acta Oncol. Madr. 2013, 52, 736-744. [CrossRef]

78. Brændengen, M.; Tveit, K.M.; Bruheim, K.; Cvancarova, M.; Berglund, K.; Glimelius, B. Late patient-reported toxicity after preoperative radiotherapy or chemoradiotherapy in nonresectable rectal cancer: Results from a randomized phase III study. Int. J. Radiat. Oncol. Biol. Phys. 2011, 81, 1017-1024. [CrossRef]

79. Kachnic, L.A.; Tsai, H.K.; Coen, J.J.; Blaszkowsky, L.S.; Hartshorn, K.; Kwak, E.L.; Willins, J.D.; Ryan, D.P.; Hong, T.S. Dose-painted intensity-modulated radiation therapy for anal cancer: A multi-institutional report of acute toxicity and response to therapy. Int. J. Radiat. Oncol. Biol. Phys. 2012, 6, 413-421. [CrossRef]

80. Muirhead, R.; Partridge, M.; Hawkins, M.A. A tumor control probability model for anal squamous cell carcinoma. Radiother. Oncol. 2015, 116, 192-196. [CrossRef]

81. Milano, M.T.; Jani, A.B.; Farrey, K.J.; Rash, C.; Heimann, R.; Chmura, S.J. Intensity-modulated radiation therapy (IMRT) in the treatment of anal cancer: Toxicity and clinical outcome. Int. J. Radiat. Oncol. Biol. Phys. 2005, 63, 354-361. [CrossRef]

82. Franco, P.; Mistrangelo, M.; Arcadipane, F.; Munoz, F.; Sciacero, P.; Spadi, R.; Migliaccio, F.; Angelini, V.; Bombaci, S.; Rondi, N.; et al. Intensity-modulated radiation therapy with simultaneous integrated boost combined with concurrent chemotherapy for the treatment of anal cancer patients: 4-year results of a consecutive case series. Cancer Invest. 2015, 33, 259-266. [CrossRef]

83. Yates, A.; Carroll, S.; Kneebone, A.; Tse, R.; Horvath, L.; Byrne, C.; Solomon, M.; Hruby, G. Implementing intensity-modulated radiotherapy with simultaneous integrated boost for anal cancer: 3 year outcomes at two Sydney institutions. Clin. Oncol. 2015, 27, 700-707. [CrossRef] [PubMed]

84. Call, J.A.; Prendergast, B.M.; Jensen, L.G.; Ord, C.B.; Goodman, K.A.; Jacob, R.; Mell, L.K.; Thomas, C.R.; Jabbour, S.K.; Miller, R.C. Intensity-modulated radiation therapy for anal cancer results from a multi-institutional retrospective cohort study. Am. J. Clin. Oncol. Cancer Clin. Trials 2016, 39, 8-12.

85. Shridhar, R.; Shibata, D.; Chan, E.; Thomas, C.R. Anal cancer: Current standards in care and recent changes in practice. CA. Cancer J. Clin. 2015, 65, 139-162. [CrossRef]

86. Pepek, J.M.; Willett, C.G.; Wu, Q.J.; Yoo, S.; Clough, R.W.; Czito, B.G. Intensity-modulated radiation therapy for anal malignancies: A preliminary toxicity and disease outcomes analysis. Int. J. Radiat. Oncol. Biol. Phys. 2010, 78, 1413-1419. [CrossRef] [PubMed]

87. DeFoe, S.G.; Beriwal, S.; Jones, H.; Rakfal, S.; Heron, D.E.; Kabolizadeh, P.; Smith, R.P.; Lalonde, R. Concurrent Chemotherapy and Intensity-modulated Radiation Therapy for Anal-Clinical Outcomes in a Large National Cancer Institute-designated Integrated Cancer Centre Network. Clin. Oncol. 2012, 24, 424-431. [CrossRef]

88. Vieillot, S.; Fenoglietto, P.; Lemanski, C.; Moscardo, C.L.; Gourgou, S.; Dubois, J.B.; Aillères, N.; Azria, D. IMRT for locally advanced anal cancer: Clinical experience of the Montpellier Cancer Center. Radiat. Oncol. 2012, 7, 45. [CrossRef]

89. Han, K.; Cummings, B.J.; Lindsay, P.; Skliarenko, J.; Craig, T.; Le, L.W.; Brierley, J.; Wong, R.; Dinniwell, R.; Bayley, A.J.; et al. Prospective evaluation of acute toxicity and quality of life after IMRT and concurrent chemotherapy for anal canal and perianal cancer. Int. J. Radiat. Oncol. 2014, 90, 587-594. [CrossRef]

90. Janssen, S.; Glanzmann, C.; Bauerfeind, P.; Stieb, S.; Studer, G.; Brown, M.; Riesterer, O. Clinical experience of SIB-IMRT in anal cancer and selective literature review. Radiat. Oncol. 2014, 9, 199. [CrossRef]

91. Mitchell, M.P.; Abboud, M.; Crane, C.H.; Eng, C.; Chang, G.J.; Rodriguez-Bigas, M.A.; Skibber, J.M.; You, Y.N.; Beddar, S.; Krishnan, S.; et al. Intensity-modulated radiation therapy (IMRT) with concurrent chemotherapy for anal cancer: A large single-institution experience. J. Clin. Oncol. 2012, 30, 661. [CrossRef]

92. Belgioia, L.; Vagge, S.; Agnese, D.; Garelli, S.; Murialdo, R.; Fornarini, G.; Chiara, S.; Gallo, F.; Bacigalupo, A.; Corvò, R. Intensified intensity-modulated radiotherapy in anal cancer with prevalent HPV p16 positivity. World J. Gastroenterol. 2015, 21, 10688-10696. [CrossRef]

93. Saarilahti, K.; Arponen, P.; Vaalavirta, L.; Tenhunen, M. The effect of intensity-modulated radiotherapy and high dose rate brachytherapy on acute and late radiotherapy-related adverse events following chemoradiotherapy of anal cancer. Radiother. Oncol. 2008, 87, 383-390. [CrossRef] 
94. Bazan, J.G.; Hara, W.; Hsu, A.; Kunz, P.A.; Ford, J.; Fisher, G.A.; Welton, M.L.; Shelton, A.; Kapp, D.S.; Koong, A.C.; et al. Intensity-modulated radiation therapy versus conventional radiation therapy for squamous cell carcinoma of the anal canal. Cancer 2011, 117, 3342-3351. [CrossRef]

95. Dewas, C.V.; Maingon, P.; Dalban, C.; Petitfils, A.; Peignaux, K.; Truc, G.; Martin, E.; Khoury, C.; Dewas, S.; Créhange, G. Does gap-free intensity modulated chemoradiation therapy provide a greater clinical benefit than $3 \mathrm{D}$ conformal chemoradiation in patients with anal cancer? Radiat. Oncol. 2012, 7, 1-10. [CrossRef]

96. Chuong, M.D.; Freilich, J.M.; Hoffe, S.E.; Fulp, W.; Weber, J.M.; Almhanna, K.; Dinwoodie, W.; Rao, N.; Meredith, K.L.; Shridhar, $\mathrm{R}$. Intensity-modulated radiation therapy vs. 3D conformal radiation therapy for squamous cell carcinoma of the anal canal. Gastrointest. Cancer Res. 2013, 6, 39-45. [PubMed]

97. Koerber, S.A.; Slynko, A.; Haefner, M.F.; Krug, D.; Schoneweg, C.; Kessel, K.; Kopp-Schneider, A.; Herfarth, K.; Debus, J.; Sterzing, F. Efficacy and toxicity of chemoradiation in patients with anal cancer-A retrospective analysis. Radiat. Oncol. 2014, 9, 113. [CrossRef]

98. Zagar, T.M.; Willett, C.G.; Czito, B.G. Intensity-modulated radiation therapy for anal cancer: Toxicity versus Outcomes. Oncology 2010, 9, 113.

99. Mitra, D.; Hong, T.S.; Horick, N.; Rose, B.; Drapek, L.N.; Blaszkowsky, L.S.; Allen, J.N.; Kwak, E.L.; Murphy, J.E.; Clark, J.W.; et al. Long-term outcomes and toxicities of a large cohort of anal cancer patients treated with dose-painted IMRT per RTOG 0529. Adv. Radiat. Oncol. 2017, 2, 110-117. [CrossRef]

100. Arcadipane, F.; Franco, P.; Ceccarelli, M.; Furfaro, G.; Rondi, N.; Trino, E.; Martini, S.; Iorio, G.C.; Mistrangelo, M.; Cassoni, P.; et al. Image-guided IMRT with simultaneous integrated boost as per RTOG 0529 for the treatment of anal cancer. Asia. Pac. J. Clin. Oncol. 2018, 14, 217-223. [CrossRef]

101. Franco, P.; De Bari, B.; Arcadipane, F.; Lepinoy, A.; Ceccarelli, M.; Furfaro, G.; Mistrangelo, M.; Cassoni, P.; Valgiusti, M.; Passardi, A.; et al. Comparing simultaneous integrated boost vs sequential boost in anal cancer patients: Results of a retrospective observational study. Radiat. Oncol. 2018, 13, 172. [CrossRef]

102. Lee, S.H.; Kim, T.H.; Kim, D.Y.; Cho, K.H.; Kim, J.Y.; Park, S.Y.; Kim, D.H.; Lim, S.B.; Choi, H.S.; Chang, H.J. The Effect of Belly Board Location in Rectal Cancer Patients Treated with Preoperative Radiotherapy. Clin. Oncol. 2006, 18, 441-446. [CrossRef]

103. Tae, H.K.; Eui, K.C.; Dae, Y.K.; Sung, Y.P.; Kwan, H.C.; Kyung, H.J.; Young, H.K.; Dae, K.S.; Jeong, S.Y.; Park, J.G. Comparison of the belly board device method and the distended bladder method for reducing irradiated small bowel volumes in preoperative radiotherapy of rectal cancer patients. Int. J. Radiat. Oncol. Biol. Phys. 2005, 64, 769-775.

104. Briere, T.M.; Crane, C.H.; Beddar, S.; Bhosale, P.; Mok, H.; Delclos, M.E.; Krishnan, S.; Das, P. Reproducibility and genital sparing with a vaginal dilator used for female anal cancer patients. Radiother. Oncol. 2012, 104, 161-166. [CrossRef] [PubMed]

105. Joseph, K.; Rose, B.; Warkentin, H.; Yun, J.; Ghosh, S.; Tankel, K. Peri-anal surface dose in anal canal VMAT radiotherapy. J. Med. Imaging Radiat. Oncol. 2018, 62, 734-738. [CrossRef]

106. Das, I.J.; Lanciano, R.M.; Movsas, B.; Kagawa, K.; Barnes, S.J. Efficacy of a belly board device with CT-simulation in reducing small bowel volume within pelvic irradiation fields. Int. J. Radiat. Oncol. Biol. Phys. 1997, 39, 67-76. [CrossRef]

107. Anderson, C.; Koshy, M.; Staley, C.; Esiashvili, N.; Ghavidel, S.; Fowler, Z.; Fox, T.; Esteves, F.; Landry, J.; Godette, K. PET-CT Fusion in Radiation Management of Patients with Anorectal Tumors. Int. J. Radiat. Oncol. Biol. Phys. 2007, 69, 155-162. [CrossRef]

108. Myerson, R.J.; Garofalo, M.C.; El Naqa, I.; Abrams, R.A.; Apte, A.; Bosch, W.R.; Das, P.; Gunderson, L.L.; Hong, T.S.; Kim, J.J.J.; et al. Elective Clinical Target Volumes for Conformal Therapy in Anorectal Cancer: A Radiation Therapy Oncology Group Consensus Panel Contouring Atlas. Int. J. Radiat. Oncol. Biol. Phys. 2009, 74, 824-830. [CrossRef]

109. Lengelé, B.; Scalliet, P. Anatomical bases for the radiological delineation of lymph node areas. Part III: Pelvis and lower limbs. Radiother. Oncol. 2009, 92, 22-33. [CrossRef]

110. Ng, M.; Leong, T.; Chander, S.; Chu, J.; Kneebone, A.; Carroll, S.; Wiltshire, K.; Ngan, S.; Kachnic, L. Australasian Gastrointestinal Trials Group (AGITG) contouring atlas and planning guidelines for intensity-modulated radiotherapy in anal cancer. Int. J. Radiat. Oncol. Biol. Phys. 2012, 83, 1455-1462. [CrossRef]

111. Gay, H.A.; Barthold, H.J.; O’Meara, E.; Bosch, W.R.; El Naqa, I.; Al-Lozi, R.; Rosenthal, S.A.; Lawton, C.; Lee, W.R.; Sandler, H.; et al. Pelvic normal tissue contouring guidelines for radiation therapy: A radiation therapy oncology group consensus panel atlas. Int. J. Radiat. Oncol. Biol. Phys. 2012, 83, e353-e362. [CrossRef]

112. Eng, C.; Chang, G.J.; Das, P.; Rodriguez-Bigas, M.; Skibber, J.M.; Qiao, W.; Rosner, G.L.; Ukegbu, L.T.; Wolff, R.A.; Crane, C.H. Phase II study of capecitabine and oxaliplatin with concurrent radiation therapy (XELOX-XRT) for squamous cell carcinoma of the anal canal. J. Clin. Oncol. 2009, 27, 4116. [CrossRef]

113. Ugurluer, G.; Ballerini, G.; Moeckli, R.; Matzinger, O.; Bourhis, J.; Ozsahin, M. Helical tomotherapy for the treatment of anal canal cancer: A dosimetric comparison with 3D conformal radiotherapy. Tumori 2015, 101, 268-272. [CrossRef] [PubMed]

114. Vieillot, S.; Azria, D.; Lemanski, C.; Moscardo, C.L.; Gourgou, S.; Dubois, J.B.; Aillères, N.; Fenoglietto, P. Plan comparison of volumetric-modulated arc therapy (RapidArc) and conventional intensity-modulated radiation therapy (IMRT) in anal canal cancer. Radiat. Oncol. 2010, 5, 92. [CrossRef]

115. Cendales, R.; Vásquez, J.; Arbelaez, J.; Bobadilla, I.; Torres, F.; Gaitan, A. IMRT, Rapidarc ${ }^{\circledR}$ and conformal radiotherapy in the treatment of tumours of the anal canal. Ecancermedicalscience 2014, 8, 469. 
116. Tozzi, A.; Cozzi, L.; Iftode, C.; Ascolese, A.; Campisi, M.C.; Clerici, E.; Comito, T.; De Rose, F.D.; Fogliata, A.; Franzese, C.; et al. Radiation therapy of anal canal cancer: From conformal therapy to volumetric modulated arc therapy. BMC Cancer 2014, 14, 833. [CrossRef]

117. Rose, B.; Mitra, D.; Hong, T.S.; Jee, K.W.; Niemierko, A.; Drapek, L.N.; Blaszkowsky, L.S.; Allen, J.N.; Murphy, J.E.; Clark, J.W.; et al. Irradiation of anatomically defined pelvic subsites and acute hematologic toxicity in anal cancer patients undergoing chemoradiation. Pract. Radiat. Oncol. 2017, 7, e291-e297. [CrossRef] [PubMed]

118. Bazan, J.G.; Luxton, G.; Mok, E.C.; Koong, A.C.; Chang, D.T. Normal tissue complication probability modeling of acute hematologic toxicity in patients treated with intensity-modulated radiation therapy for squamous cell carcinoma of the anal canal. Int. J. Radiat. Oncol. Biol. Phys. 2012, 84, 700-706. [CrossRef]

119. Lee, A.Y.; Golden, D.W.; Bazan, J.G.; Kopec, M.; Pelizzari, C.A.; Aggarwal, S.; Chang, D.T.; Liauw, S.L. Hematologic Nadirs During Chemoradiation for Anal Cancer: Temporal Characterization and Dosimetric Predictors. Int. J. Radiat. Oncol. Biol. Phys. 2017, 97, 306-312. [CrossRef] [PubMed]

120. Franco, P.; Fiandra, C.; Arcadipane, F.; Trino, E.; Giglioli, F.R.; Ragona, R.; Ricardi, U. Incorporating 18FDG-PET-defined pelvic active bone marrow in the automatic treatment planning process of anal cancer patients undergoing chemo-radiation. $B M C$ Cancer 2017, 17, 710. [CrossRef]

121. Arcadipane, F.; Silvetti, P.; Olivero, F.; Gastino, A.; De Luca, V.; Mistrangelo, M.; Cassoni, P.; Racca, P.; Gallio, E.; Lesca, A.; et al. Bone marrow-sparing IMRT in anal cancer patients undergoing concurrent chemo-radiation: Results of the first phase of a prospective phase II trial. Cancers 2020, 12, 3306. [CrossRef]

122. Mirabeau-Beale, K.; Hong, T.S.; Niemierko, A.; Ancukiewicz, M.; Blaszkowsky, L.S.; Crowley, E.M.; Cusack, J.C.; Drapek, L.C.; Kovalchuk, N.; Markowski, M.; et al. Clinical and treatment factors associated with vaginal stenosis after definitive chemoradiation for anal canal cancer. Pract. Radiat. Oncol. 2015, 5, e113-e118. [CrossRef]

123. Marshall, D.C.; Ghiassi-Nejad, Z.; Powers, A.R.; Argiriadi, P.; Reidenberg, J.S.; Ru, M.; Dumane, V.A.; Buckstein, M.; Goodman, K.A.; Schnur, J.; et al. A Dosimetric Comparison Of A Novel Clitoris-Sparing Intensity Modulated Radiotherapy (IMRT) Approach vs. Standard IMRT for Treatment of Female Patients with Anal Cancer. Int. J. Radiat. Oncol. 2020, 108, e636. [CrossRef]

124. Arians, N.; Häfner, M.; Krisam, J.; Lang, K.; Wark, A.; Koerber, S.A.; Hommertgen, A.; Debus, J. Intrafractional vaginal dilation in anal cancer patients undergoing pelvic radiotherapy (DILANA)- A prospective, randomized, 2-armed phase-II-trial. BMC Cancer 2020, 20, 52-58. [CrossRef]

125. Glynne-Jones, R.; Sebag-Montefiore, D.; Meadows, H.M.; Cunningham, D.; Begum, R.; Adab, F.; Benstead, K.; Harte, R.J.; Stewart, J.; Beare, S.; et al. Best time to assess complete clinical response after chemoradiotherapy in squamous cell carcinoma of the anus (ACT II): A post-hoc analysis of randomised controlled phase 3 trial. Lancet Oncol. 2017, 18, 347-356. [CrossRef]

126. Cummings, B.J. Concomitant radiotherapy and chemotherapy for anal cancer. Semin.Oncol. 1992, 19, $102-108$.

127. Mackowski, A.; Levitt, M.; Makin, G.; Salama, P.; Tan, P.; Penter, C.; Platell, C. Anal squamous cell carcinoma: Are we improving outcomes? ANZ J. Surg. 2018, 88, 1013-1016. [CrossRef] [PubMed]

128. Dee, E.C.; Eyler, C.E.; Sanford, N.N.; Wo, J.Y. Local Therapy Options for Recurrent Rectal and Anal Cancer: Current Strategies and New Directions. Curr. Colorectal Cancer Rep. 2019, 15, 157-169. [CrossRef]

129. Hallemeier, C.L.; You, Y.N.; Larson, D.W.; Dozois, E.J.; Nelson, H.; Klein, K.A.; Miller, R.C.; Haddock, M.G. Multimodality therapy including salvage surgical resection and intraoperative radiotherapy for patients with squamous-cell carcinoma of the anus with residual or recurrent disease after primary chemoradiotherapy. Dis. Colon Rectum 2014, 57, 442-448. [CrossRef]

130. Renehan, A.G.; O’Dwyer, S.T. Management of Local Disease Relapse. Color. Dis. 2011, 13, 44-52. [CrossRef]

131. Bignell, M.; Chave, H.; Branagan, G. Outcome of surgery for recurrent anal cancer: Results from a tertiary referral centre. Color. Dis. 2018, 20, 771-777. [CrossRef]

132. Pesi, B.; Scaringi, S.; Di Martino, C.; Batignani, G.; Giudici, F.; Bisogni, D.; Tonelli, F.; Bechi, P. Results of Surgical Salvage Treatment for Anal Canal Cancer: A Retrospective Analysis with Overview of the Literature. Dig. Surg. 2017, 34, 380-386. [CrossRef]

133. Akbari, R.P.; Paty, P.B.; Guillem, J.G.; Weiser, M.R.; Temple, L.K.; Minsky, B.D.; Saltz, L.; Wong, W.D. Oncologic outcomes of salvage surgery for epidermoid carcinoma of the anus initially managed with combined modality therapy. Dis. Colon Rectum 2004, 47, 1136-1144. [CrossRef]

134. Schiller, D.E.; Cummings, B.J.; Rai, S.; Le, L.W.; Last, L.; Davey, P.; Easson, A.; Smith, A.J.; Swallow, C.J. Outcomes of salvage surgery for squamous cell carcinoma of the anal canal. Ann. Surg. Oncol. 2007, 14, 2780-2789. [CrossRef] [PubMed]

135. Mullen, J.T.; Rodriguez-Bigas, M.A.; Chang, G.J.; Barcenas, C.H.; Crane, C.H.; Skibber, J.M.; Feig, B.W. Results of surgical salvage after failed chemoradiation therapy for epidermoid carcinoma of the anal canal. Ann. Surg. Oncol. 2007, 14, 478-483. [CrossRef]

136. Hannes, S.; Reinisch, A.; Bechstein, W.O.; Habbe, N. Salvage abdominoperineal excisions in recurrent anal cancer-impact of different reconstruction techniques on outcome, morbidity, and complication rates. Int. J. Colorectal Dis. 2016, 31, 653-659. [CrossRef] [PubMed]

137. Ellenhorn, J.D.I.; Enker, W.E.; Quan, S.H.Q. Salvage abdominoperineal resection following combined chemotherapy and radiotherapy for epidermoid carcinoma of the anus. Ann. Surg. Oncol. 1994, 1, 105-110. [CrossRef]

138. Hagemans, J.A.W.; Blinde, S.E.; Nuyttens, J.J.; Morshuis, W.G.; Mureau, M.A.M.; Rothbarth, J.; Verhoef, C.; Burger, J.W.A. Salvage Abdominoperineal Resection for Squamous Cell Anal Cancer: A 30-Year Single-Institution Experience. Ann. Surg. Oncol. 2018, 25, 1970-1979. [CrossRef] [PubMed] 
139. Nilsson, P.J.; Svensson, C.; Goldman, S.; Glimelius, B. Salvage abdominoperineal resection in anal epidermoid cancer. Br. J. Surg. 2002, 89, 1425-1429. [CrossRef]

140. Severino, N.P.; Chadi, S.A.; Rosen, L.; Coiro, S.; Choman, E.; Berho, M.; Wexner, S.D. Survival following salvage abdominoperineal resection for persistent and recurrent squamous cell carcinoma of the anus: Do these disease categories affect survival? Color. Dis. 2016, 18, 959-966. [CrossRef]

141. Singh, M.; Kinsley, S.; Huang, A.; Ricci, J.A.; Clancy, T.E.; Irani, J.; Goldberg, J.; Breen, E.; Bleday, R.; Talbot, S.G. Gracilis Flap Reconstruction of the Perineum: An Outcomes Analysis. J. Am. Coll. Surg. 2016, 223, 602-610. [CrossRef]

142. Chessin, D.B.; Hartley, J.; Cohen, A.M.; Mazumdar, M.; Cordeiro, P.; Disa, J.; Mehrara, B.; Minsky, B.D.; Paty, P.; Weiser, M.; et al. Rectus flap reconstruction decreases perineal wound complications after pelvic chemoradiation and surgery: A cohort study. Ann. Surg. Oncol. 2005, 12, 104-110. [CrossRef]

143. Eng, C.; Chang, G.J.; You, Y.N.; Das, P.; Rodriguez-Bigas, M.; Xing, Y.; Vauthey, J.-N.; Rogers, J.E.; Ohinata, A.; Pathak, P.; et al. The role of systemic chemotherapy and multidisciplinary management in improving the overall survival of patients with metastatic squamous cell carcinoma of the anal canal. Oncotarget 2015, 5, 11133-11142. [CrossRef]

144. Benson, A.B.; Venook, A.P.; Al-Hawary, M.M.; Cederquist, L.; Chen, Y.; Ciombor, K.K.; Cohen, S.; Cooper, H.S.; Deming, D.; Engstrom, P.F. Anal Carcinoma, Version 2.2018, NCCN Clinical Practice Guidelines in Oncology. Available online: https: / /jnccn.org/view/journals/jnccn/16/7/article-p852.xml (accessed on 9 March 2021).

145. Sclafani, F.; Morano, F.; Cunningham, D.; Baratelli, C.; Kalaitzaki, E.; Watkins, D.; Starling, N.; Chau, I.; Rao, S. PlatinumFluoropyrimidine and Paclitaxel-Based Chemotherapy in the Treatment of Advanced Anal Cancer Patients. Oncologist 2017, 22, 402-408. [CrossRef]

146. Rao, S.; Sclafani, F.; Eng, C.; Adams, R.A.; Guren, M.G.; Sebag-Montefiore, D.; Benson, A.; Bryant, A.; Peckitt, C.; Segelov, E.; et al. International rare cancers initiative multicenter randomized phase II trial of cisplatin and fluorouracil versus carboplatin and paclitaxel in advanced anal cancer: InterAAct. J. Clin. Oncol. 2020, 38, 2510-2518. [CrossRef]

147. Kim, S.; François, E.; André, T.; Samalin, E.; Jary, M.; El Hajbi, F.; Baba-Hamed, N.; Pernot, S.; Kaminsky, M.C.; Bouché, O.; et al. Docetaxel, cisplatin, and fluorouracil chemotherapy for metastatic or unresectable locally recurrent anal squamous cell carcinoma (Epitopes-HPV02): A multicentre, single-arm, phase 2 study. Lancet Oncol. 2018, 19, 1094-1106. [CrossRef]

148. Strauss, J.; Gatti-Mays, M.E.; Redman, J.; Madan, R.A.; Lamping, E.; Manu, M.; Burmeister, A.; Marte, J.L.; Cordes, L.M.; Ojalvo, L.; et al. Safety and activity of M7824, a bifunctional fusion protein targeting PD-L1 and TGF- $\beta$, in patients with HPV associated cancers. J. Clin. Oncol. 2018, 36, 3007. [CrossRef]

149. Ott, P.A.; Piha-Paul, S.A.; Munster, P.; Pishvaian, M.J.; van Brummelen, E.M.J.; Cohen, R.B.; Gomez-Roca, C.; Ejadi, S.; Stein, M.; Chan, E.; et al. Safety and antitumor activity of the anti-PD-1 antibody pembrolizumab in patients with recurrent carcinoma of the anal canal. Ann. Oncol. Off. J. Eur. Soc. Med. Oncol. 2017, 28, 1036-1041. [CrossRef]

150. Osborne, E.M.; Eng, C.; Skibber, J.M.; Rodriguez-Bigas, M.A.; Chang, G.J.; Nancy You, Y.Q.; Bednarski, B.K.; Minsky, B.D.; Delclos, M.E.; Koay, E.; et al. Hyperfractionated accelerated reirradiation for patients with recurrent anal cancer previously treated with definitive chemoradiation. Am. J. Clin. Oncol. Cancer Clin. Trials 2018, 41, 632-637. [CrossRef]

151. Wright, J.L.; Gollub, M.J.; Weiser, M.R.; Saltz, L.B.; Wong, W.D.; Paty, P.B.; Temple, L.K.; Guillem, J.G.; Minsky, B.D.; Goodman, K.A. Surgery and high-dose-rate intraoperative radiation therapy for recurrent squamous-cell carcinoma of the anal canal. Dis. Colon Rectum 2011, 54, 1090-1097. [CrossRef]

152. Ojerholm, E.; Kirk, M.L.; Thompson, R.F.; Zhai, H.; Metz, J.M.; Both, S.; Ben-Josef, E.; Plastaras, J.P. Pencil-beam scanning proton therapy for anal cancer: A dosimetric comparison with intensity-modulated radiotherapy. Acta Oncol. 2015, 54, 1209-1217. [CrossRef] [PubMed]

153. Meyer, J.; Czito, B.; Yin, F.F.; Willett, C. Advanced radiation therapy technologies in the treatment of rectal and anal cancer: Intensity-modulated photon therapy and proton therapy. Clin. Colorectal Cancer 2007, 6, 348-356. [CrossRef]

154. Anand, A.; Bues, M.; Rule, W.G.; Keole, S.R.; Beltran, C.J.; Yin, J.; Haddock, M.G.; Hallemeier, C.L.; Miller, R.C.; Ashman, J.B. Scanning proton beam therapy reduces normal tissue exposure in pelvic radiotherapy for anal cancer. Radiother. Oncol. 2015, 117, 505-508. [CrossRef]

155. Wo, J.Y.; Ben-Josef, E.; Yeap, B.Y.; Jiang, W.; DeLaney, T.F.; Ryan, D.P.; Metz, J.M.; Drapek, L.C.; Allen, J.N.; Clark, J.W.; et al. A Pilot Feasibility Study of Definitive Concurrent Chemoradiation with Pencil Beam Scanning Proton Beam in Combination with 5-fluorouracil and Mitomycin-c for Carcinoma of the Anal Canal. Int. J. Radiat. Oncol. Biol. Phys. 2018, 102, S63. [CrossRef]

156. Colaco, R.J.; Nichols, R.C.; Huh, S.; Getman, N.; Ho, M.W.; Li, Z.; Morris, C.G.; Mendenhall, W.M.; Mendenhall, N.P.; Hoppe, B.S. Protons offer reduced bone marrow, small bowel, and urinary bladder exposure for patients receiving neoadjuvant radiotherapy for resectable rectal cancer. J. Gastrointest. Oncol. 2014, 5, 3-8. [PubMed]

157. Sebag-Montefiore, D.; Adams, R.; Bell, S.; Berkman, L.; Gilbert, D.C.; Glynne-Jones, R.; Goh, V.; Gregory, W.; Harrison, M.; Kachnic, L.A.; et al. The Development of an Umbrella Trial (PLATO) to Address Radiation Therapy Dose Questions in the Locoregional Management of Squamous Cell Carcinoma of the Anus. Int. J. Radiat. Oncol. 2016, 96, E164-E165. [CrossRef]

158. Doll, C.M.; Moughan, J.; Klimowicz, A.; Ho, C.K.; Kornaga, E.N.; Lees-Miller, S.P.; Ajani, J.A.; Crane, C.H.; Kachnic, L.A.; Okawara, G.S.; et al. Significance of Co-expression of Epidermal Growth Factor Receptor and Ki67 on Clinical Outcome in Patients With Anal Cancer Treated With Chemoradiotherapy: An Analysis of NRG Oncology RTOG 9811. Int. J. Radiat. Oncol. 2017, 97, 554-562. [CrossRef] 
159. Garg, M.K.; Zhao, F.; Sparano, J.A.; Palefsky, J.; Whittington, R.; Mitchell, E.P.; Mulcahy, M.F.; Armstrong, K.I.; Nabbout, N.H.; Kalnicki, S.; et al. Cetuximab plus chemoradiotherapy in immunocompetent patients with anal carcinoma: A phase II Eastern cooperative oncology group-American college of radiology imaging network cancer research group trial (E3205). J. Clin. Oncol. 2017, 35, 718-726. [CrossRef] [PubMed]

160. Sparano, J.A.; Lee, J.Y.; Palefsky, J.; Henry, D.H.; Wachsman, W.; Rajdev, L.; Aboulafia, D.; Ratner, L.; Fitzgerald, T.J.; Kachnic, L.; et al. Cetuximab plus chemoradiotherapy for HIV-associated anal carcinoma: A phase II AIDS malignancy consortium trial. J. Clin. Oncol. 2017, 35, 727-733. [CrossRef]

161. Safran, H.; Leonard, K.L.; Perez, K.; Vrees, M.; Klipfel, A.; Schechter, S.; Oldenburg, N.; Roth, L.; Shah, N.; Rosati, K.; et al. Tolerability of ADXS11-001 Lm-LLO Listeria-Based Immunotherapy With Mitomycin, Fluorouracil, and Radiation for Anal Cancer. Int. J. Radiat. Oncol. Biol. Phys. 2018, 100, 1175-1178. [CrossRef]

162. Safran, H.; Leonard, K.L.; DiPetrillo, T.A.; Klipfel, A.; Schechter, S.; Oldenburg, N.; Vrees, M.; Roth, L.; Shah, N.; Mantripragada, K.C.; et al. ADXS11-001 Lm-LLO Immunotherapy, Mitomycin, 5-fluorouracil (5-FU) and Intensity-modulated radiation therapy (IMRT) for Anal Cancer. J. Clin. Oncol. 2017, 35, e15072. [CrossRef]

163. Das, P.; Bhatia, S.; Eng, C.; Ajani, J.A.; Skibber, J.M.; Rodriguez-Bigas, M.A.; Chang, G.J.; Bhosale, P.; Delclos, M.E.; Krishnan, S.; et al. Predictors and Patterns of Recurrence After Definitive Chemoradiation for Anal Cancer. Int. J. Radiat. Oncol. Biol. Phys. 2007, 68, 794-800. [CrossRef] [PubMed]

164. Eng, C. Anal cancer: Current and future methodology. Cancer Investig. 2006, 24, 535-544. [CrossRef]

165. Ajani, J.A.; Carrasco, C.H.; Jackson, D.E.; Wallace, S. Combination of cisplatin plus fluoropyrimidine chemotherapy effective against liver metastases from carcinoma of the anal canal. Am. J. Med. 1989, 878, 221-224. [CrossRef]

166. Ishida, Y.; Agata, Y.; Shibahara, K.; Honjo, T. Induced expression of PD-1, a novel member of the immunoglobulin gene superfamily, upon programmed cell death. EMBO J. 1992, 11, 3887-3895. [CrossRef]

167. Freeman, G.J.; Long, A.J.; Iwai, Y.; Bourque, K.; Chernova, T.; Nishimura, H.; Fitz, L.J.; Malenkovich, N.; Okazaki, T.; Byrne, M.C.; et al. Engagement of the PD-1 immunoinhibitory receptor by a novel B7 family member leads to negative regulation of lymphocyte activation. J. Exp. Med. 2000, 192, 1027-1034. [CrossRef] 